\title{
Battery Energy Storage System for Emergency Supply and Improved Reliability of Power Networks
}

\author{
Marcin Szott, Szymon Wermiński *, Marcin Jarnut, Jacek Kaniewski and Grzegorz Benysek
}

Citation: Szott, M.; Wermiński, S.; Jarnut, M.; Kaniewski, J.; Benysek, G. Battery Energy Storage System for Emergency Supply and Improved Reliability of Power Networks. Energies 2021, 14, 720. https:// doi.org/10.3390/en14030720

Academic Editor: Teuvo Suntio

Received: 4 December 2020

Accepted: 26 January 2021

Published: 30 January 2021

Publisher's Note: MDPI stays neutral with regard to jurisdictional claims in published maps and institutional affiliations.

Copyright: (c) 2021 by the authors. Licensee MDPI, Basel, Switzerland. This article is an open access article distributed under the terms and conditions of the Creative Commons Attribution (CC BY) license (https:// creativecommons.org/licenses/by/ $4.0 /)$.
Institute of Automatic Control, Electronics and Electrical Engineering, University of Zielona Góra, St Prof. Z. Szafrana 2, 65-516 Zielona Góra, Poland; m.szott@iee.uz.zgora.pl (M.S.); marcinjarnut@gmail.com (M.J.); kaniewski.jacek@gmail.com (J.K.); gbenysek@gmail.com (G.B.)

* Correspondence: s.werminski@iee.uz.zgora.pl; Tel.: +48-796-095-016
Abstract: This paper introduces the concept of a battery energy storage system as an emergency power supply for a separated power network, with the possibility of island operation for a power substation with one-side supply. This system, with an appropriately sized energy storage capacity, allows improvement in the continuity of the power supply and increases the reliability of the separated network at a specified time during the limitation of power transmission as a result of damage or disconnection of the main power line. This paper presents and describes a specific method of energy storage system dimensioning based on real measurement data. Based on the obtained parameters, an analysis of the reliability improvement of the considered network was performed. The implementation of the battery energy storage system will contribute to a more than 5-fold reduction in the occurrence of power outages in the time interval from 3 min to $1.5 \mathrm{~h}$, which will clearly reduce the System Average Interruption Frequency Index and System Average Interruption Duration Index factors. In this paper, the network conditions for operational normality and failure are presented and the cost for implementation of an energy storage system (about EUR 1 million) is compared with the possible implementation of an additional power line (about EUR 5 million) to a specific power substation.

Keywords: battery energy storage system; power network; power substation; energy backup; emergency power supply

\section{Introduction \\ 1.1. Quality Standards of Electricity}

The main role of an electric power system (EPS) is to provide uninterrupted electricity at an appropriate quality. The quality standards of electricity in public networks are defined in the European standard EN 50160 [1]. These standards define such parameters as: frequency and voltage value [2], rapid voltage changes "flicker" [3], voltage dips and swells [4], voltage asymmetry [5], and short and long power interruptions. The area that the authors focus on is power interruptions.

\subsection{Parameters Related to the Power Interuptions}

Power interruption is defined in the standard EN 50160 [1] as a supply continuity where in every week $95 \%$ of all 10 min average values of measurement samples of the individual parameter must fall within the allowable range value of this parameter [1]. However, power interruptions are not unequivocally standardized because they are highly unpredictable and occur in various places and times [1]. The EN 50160 standard only defines the duration of the break. Interruptions longer than $3 \mathrm{~min}$ are long breaks and others are defined as short breaks [6]. Therefore, the local Distribution System Operator (DSO) is responsible for the continuity of energy supplies in a specific area, and all planned and unplanned interruptions are determined by the following indicators: 
- $\quad$ System Average Interruption Duration Index (SAIDI);

- $\quad$ System Average Interruption Frequency Index (SAIFI);

- Momentary Average Interruption Frequency Index (MAIFI) [7].

With regard to the listed problems and related EN standards, in order to reduce the occurrence of interruptions in energy supply and to improve the reliability of distribution grids, it is necessary to automate and reconfigure them [8]; however, it is not possible to do so in a typical way under all grid distribution areas.

\subsection{Grid Section with Reconfiguration Difficulties}

An electrical substation supplied unilaterally from the high voltage (HV) network and those whose main power lines run in difficult areas [9] (e.g., mountains) naturally have limited ability to ensure continuity of power supply. Solutions that can support such grid sections are:

- The expansion of the substation with additional renewable energy sources (RESs) [10];

- Hybrid systems [11];

- $\quad$ Energy storage systems [12].

In this paper, the authors have focused on the energy storage system. In the literature, solutions with the use of energy storage are mainly referred to for:

- Limiting the peak value of active power, based on an annual analysis for the thermal generator and pumped storages [13];

- Voltage frequency regulation $(f)$, based on precise management of power flows by forecasting renewable energy generation, estimating the availability of energy at storage batteries, and invoking the appropriate mode of operation, based on the load demand [14].

Bearing in mind the above, the authors have not encountered a solution for the use of an energy storage system (ESS) for emergency power supply which would improve safety and comfort in a given area of the power grid.

\subsection{Literature Review}

For the dimensioning and selection of the appropriate ESS technology, there is a need to analyse the local power flow of the microgrid (MG) [15] and perform a cost analysis [16]. Another issue is the fact of controlling the intelligent MG during island operation [17] and the location of the ESS [18]. Such a system can be implemented into the structure of an electrical substation, for example, on the side of medium voltage of alternating current (MV) [19], or directly connected to a low voltage (LV) power grid [20].

The authors of the article [21] presented a battery energy storage system (BESS), the main role of which is to improve the reliability of a designated area of the MV network by limiting the peak value of active power $(P)$ and frequency regulation $(f)$ of the voltage due to the negative impact of RESs. This system can also operate in backup mode during island operation. The article [22] presents a system of real-time energy management and micgrogrid control based on RESs (photovoltaic (PV) and a diesel generator (DG)) with the ESS in grid and island operation. During island operation, the ESS is the energy source and the DG controls the voltage and frequency. The authors of article [23] describe a self-sufficient regional integrated energy system (RIES), whose power sources are wind turbines (WT) and PV cells supported by BESS. In this system, the moth flame optimization (MFO) algorithm is responsible for optimizing each unit's scheduled plan for each unit (RESs and BESS). The article [24] presents a power system whose reliability and increase in operational capacity are supported by RESs and ESSs, and the generic algorithm (GA) is responsible for the optimization of generation capacity and the operation of the ESS.

The authors of article [25] used the Monte Carlo method to determine the capacity and power of an ESS used to improve the reliability of the network operation. The method allows the determination of the probability distribution of all state variables, such as: single and double failures of the power system (transformer), failure duration and frequency, 
and state-of-charge (SoC). Paper [26] presents a cost-based formulation to determine the optimal size of the battery energy storage (BES) based on the bat algorithm, which supports fluctuation and intermittency of RESs (WT and PV). In order to determine the ESS parameters for the system operation in the network and island mode, the authors of article [27] based their result on simulation studies of WT and PV performance. The authors of article [28] present a two-step method of dimensioning and controlling BESS based on the mesh adaptive direct search (MADS) black box optimization algorithm and the improved particle swarm optimization (IPSO) algorithm. Paper [29] presents a computationally efficient optimization method to optimize the battery storage (BS) capacities based on the power exchange process of the grid-connected microgrid $(\mathrm{GC} \mu \mathrm{G})$. The author presented a heuristic two-level optimization model, which is developed with the sizing of BS as the upper level problem and the optimizing of the operational cost of the $\mathrm{GC} \mu \mathrm{G}$ as the lowerlevel problem, and to validate the accuracy and computational efficiency, the numerical results are compared with the matrix integer linear programming (MILP) method.

\subsection{Contribution of the Paper}

Based on the specific place in the power grid where the author-designed measuring points were designated in the distribution grid, the data were analysed for the worst case scenario, bearing in mind winter and summer profiles, and the projected uninterruptible power supply UPS time was correlated with the technological possibilities of connecting the energy storage system.

Distinguishing features of the main contribution are:

- Presentation of the concept for implementing BESS into a power substation on the MV side, the main role of which is to improve the reliability of the separated network area through an emergency power supply;

- Presentation of the authorial ESS ( $P_{\mathrm{ES}}$ and $E_{\mathrm{ES}}$ ) dimensioning method using the $15 \mathrm{~min}$ averaging method based on real measuring data;

- Analysis of the selection of type and technology of the energy storage based on the design data $\left(P_{\mathrm{ES}}\right.$ and $\left.E_{\mathrm{ES}}\right)$ and the designated function (emergency power supply-for an exemplary time interval $(1.0 ; 1.5 ; 2.0 \mathrm{~h})$ );

- Analysis of the impact of BESS implementation on the number of power outages (SAIFI) in the considered power grid;

- Cost comparison of the implementation of the BESS with the possible replacement or implementation of an additional HV line.

\subsection{Structure of the Paper}

In Section 2, the facility is analysed and the possible network operating conditions are presented. All stages of parameter determination for the energy storage system are presented in Section 3. In Section 3.1, the authorial ESS dimensioning method is presented, and consists of calculating the $15 \mathrm{~min}$ value of moving average active power based on the actual measurement data of a $1 \mathrm{~s}$ average active power flow. Parameter determination for the energy storage system is presented in Section 3.2, and energy storage technology selection, in Section 3.3. Spatial analysis of the energy storage system provided for the considered substation is presented in Section 3.4. Section 4 analyses the power flow of the considered system in the normal, failure and island operating conditions. Section 5 presents an analysis of the network reliability improvement, which was performed in relation to the frequency of power outages and failure. In Section 6, the costs of implementing BESS are also compared with the possible implementation of an additional power line to the considered substation. This article ends with Section 7 , a short review and main conclusions, and Section 8, a statement of plans for future research. 


\section{Description of the Considered Network}

\subsection{Network Structure}

The simplified diagram (Figure 1) shows the structure of the HV/MV network in the area which supplies the considered electrical power substation EPS " $\mathrm{A}$ ".

The HV and MV lines are overhead lines that are exposed to weather conditions (mainly gusts of wind, heavy rain and storms). These lines run in the mountain and forest areas, and the considered EPS " $\mathrm{A}$ " substation is supplied unilaterally from the $110 \mathrm{kV}$ network from substation EPS " $\mathrm{B}$ ".

As a result, this area is exposed to frequent power outages; however, the implementation of the additional overhead or cable line is disproportionate to the quantity of customers and the volume of energy distribution.

The aforementioned conditions justify the expansion of the separated area of the network with additional energy sources or an ESS that would improve the continuity of power supply.

In this power network subsystem, we will consider the following operating conditions:

- Normal operation condition-N (Figure 1);

- Failure operation condition-F-1 (in failure state of $110 \mathrm{kV}$ line) (Figure 2);

- Failure operation condition-F-2 (in failure state of $110 \mathrm{kV}$ and $30 \mathrm{kV}$ line) (Figure 3);

- Island operation condition-F-2* (without primary power sources) (Figure 4).

The critical points and network reconfiguration devices of the considered network are:

- Field switch " $\mathrm{A}$ " in EPS "B" - connection point of $30 \mathrm{kV}$ line to substation EPS " $\mathrm{A}$ ";

- Automatic circuit reclosers (ACRs)—share the $30 \mathrm{kV}$ line between EPS " $\mathrm{B}$ " and EPS "A";

- Control switchgear (CSG) " $\mathrm{A}$ "— the main switchgear in EPS " $\mathrm{A}$ " with field switches;

- Field switch " $B$ " in CSG " $A$ "—connect point of $30 \mathrm{kV}$ line from EPS " $A$ " or EPS " $B$ ";

- Switch disconnector CS in CSG " $\mathrm{A}$ "- switches the power source for an industrial plant "IP";

- Automatic transfer switch (ATS) " $\mathrm{A}$ " in EPS " $\mathrm{C}$ "—-emergency power switch on for the "IP";

- Field switch " $\mathrm{R}$ " in EPS " $\mathrm{A}$ "—-the reserve linear field (BESS will be connected at this point).

In the normal operational condition $(\mathrm{N})$ of the network, the substation EPS " $\mathrm{A}$ " is supplied from one side by the $110 \mathrm{kV}$ HV line. The $30 \mathrm{kV}$ MV field network is divided with the ACRs into the part of the power supply from the electrical substation EPS " $\mathrm{B}$ " (from the " $\mathrm{A}$ " field in the substation EPS "B" to the ACRs) and the part supplied from the $30 \mathrm{kV}$ switchgear of the station EPS "A" (Figure 1).

The following recipients are connected from the line bay of control switchgear CSG " $\mathrm{A}$ " in substation EPS " $\mathrm{A}$ ":

- Power lines to the substation EPS "C" (connected behind the sectional switch disconnector (CS));

- Several small villages (connected before CS to the EPS " $\mathrm{A}$ ");

- A large industrial recipient with high supply priority (the " $\mathrm{IP}^{\prime}$ industrial plant is connected behind the CS).

To summarize, the considered substation EPS "A" (Figure 1) supplies over 3000 consumers and the $20 \mathrm{kV}$ switchgear at EPS "A" currently supplies only the $20 / 0.4 \mathrm{kV}$ auxiliary transformer (AT), which supplies the internal equipment of EPS " $\mathrm{A}$ ". 


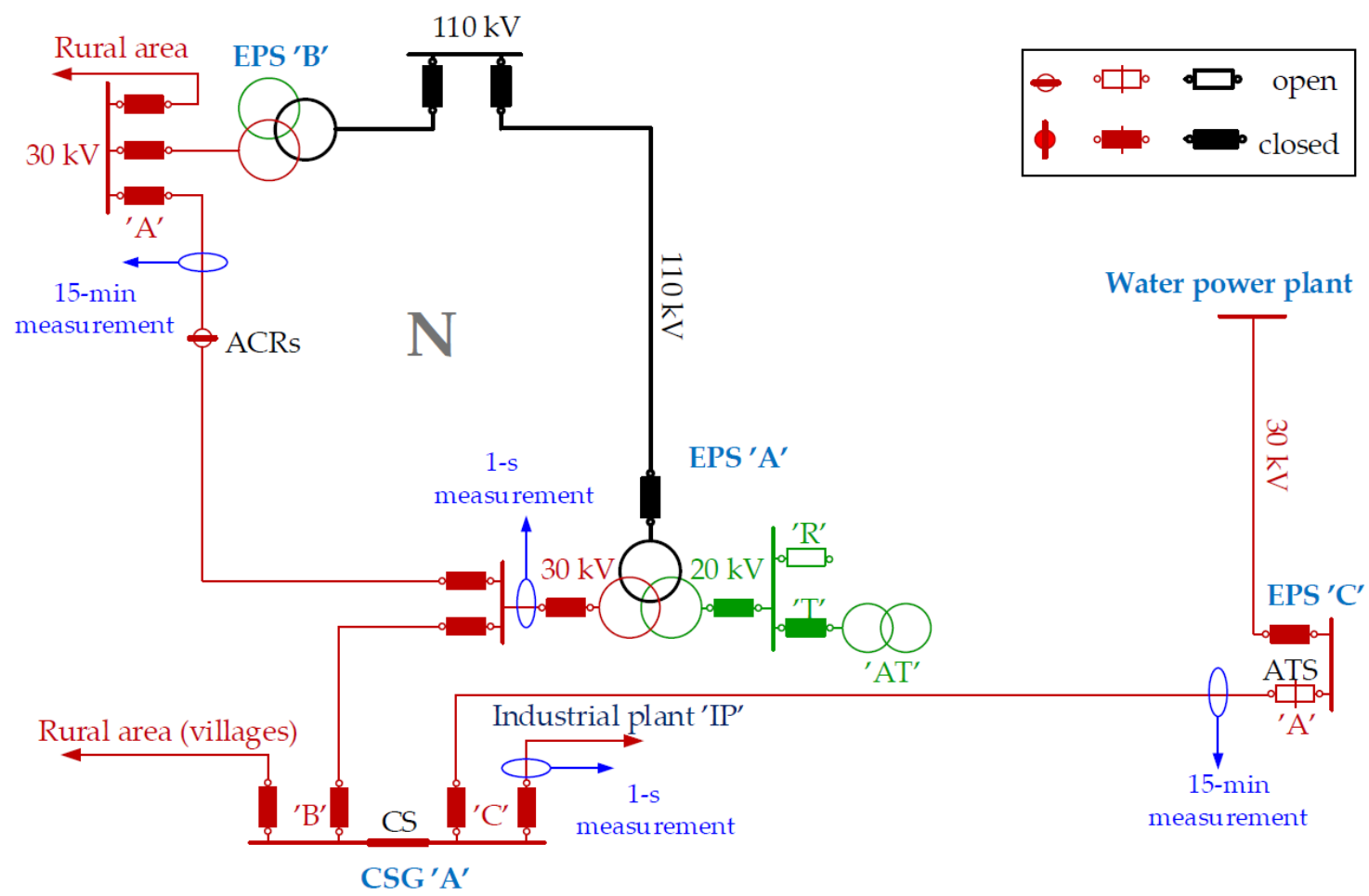

Figure 1. The system structure of the considered network in the normal operational condition N.

\subsection{Analysis of Power Failure in Normal Operational Condition}

Table 1 shows the number of outages in the considered network with HV and MV lines due to weather and environmental conditions, the effects of material aging and other factors.

Table 1. List of the failure events in lines of the considered network that occurred in 2018.

\begin{tabular}{lc}
\hline \multicolumn{1}{c}{ Reasons } & Number of Events \\
\hline $\begin{array}{l}\text { External and natural factors (flood, rain, strong gusty wind, } \\
\text { rime, icing, snow, lighting, birds and animals, close-up of } \\
\text { trees and branches) }\end{array}$ & 164 \\
\hline $\begin{array}{l}\text { Material (erosion, corrosion, weakening of electrical } \\
\text { insulation) and others }\end{array}$ & 67 \\
\hline
\end{tabular}

The one-year (2018) data contained in Table 1 are obtained from the local DSO.

The power continuity rates are affected by the extent of the distribution network, one-side power supply to the EPS " $\mathrm{A}$ " substation from the HV line, the impact of long-term events presented in Table 1 and the duration of the event in relation to the quantity of consumers covered by a given event.

Table 2 presents selected results of the event analysis, taking into account the abovementioned criteria, and presents the number of customers affected by the failure (customer in relation to SAIFI). The one-year period (2018) data are also obtained from the local DSO. 
Table 2. Summary of the number of outages for the considered network that occurred in 2018.

\begin{tabular}{ccc}
\hline Duration of Failure & Number of Events & $\begin{array}{c}\text { Number of Customers Affected by the } \\
\text { Failure (Customers in Relation to } \\
\text { SAIFI) }\end{array}$ \\
\hline from 3 min to $1.5 \mathrm{~h}$ & 74 & up to 3224 \\
\hline from $1.5 \mathrm{~h}$ to $24 \mathrm{~h}$ & 45 & up to 3224 \\
\hline longer than $24 \mathrm{~h}$ & 7 & up to 1876 \\
\hline
\end{tabular}

\subsection{Outage and Island Operating Conditions of the Considered Network}

In an outage condition state of the $110 \mathrm{kV}$ line between EPS " $\mathrm{B}$ " and EPS " $\mathrm{A}$ ", the MV $30 \mathrm{kV}$ distribution network is reconfigured to the F-1 condition (Figure 2). After the closing of the ACRs in this system, the distribution area (including the "IP") is supplied from the line field " $\mathrm{A}$ " of the substation EPS " $\mathrm{B}$ ".

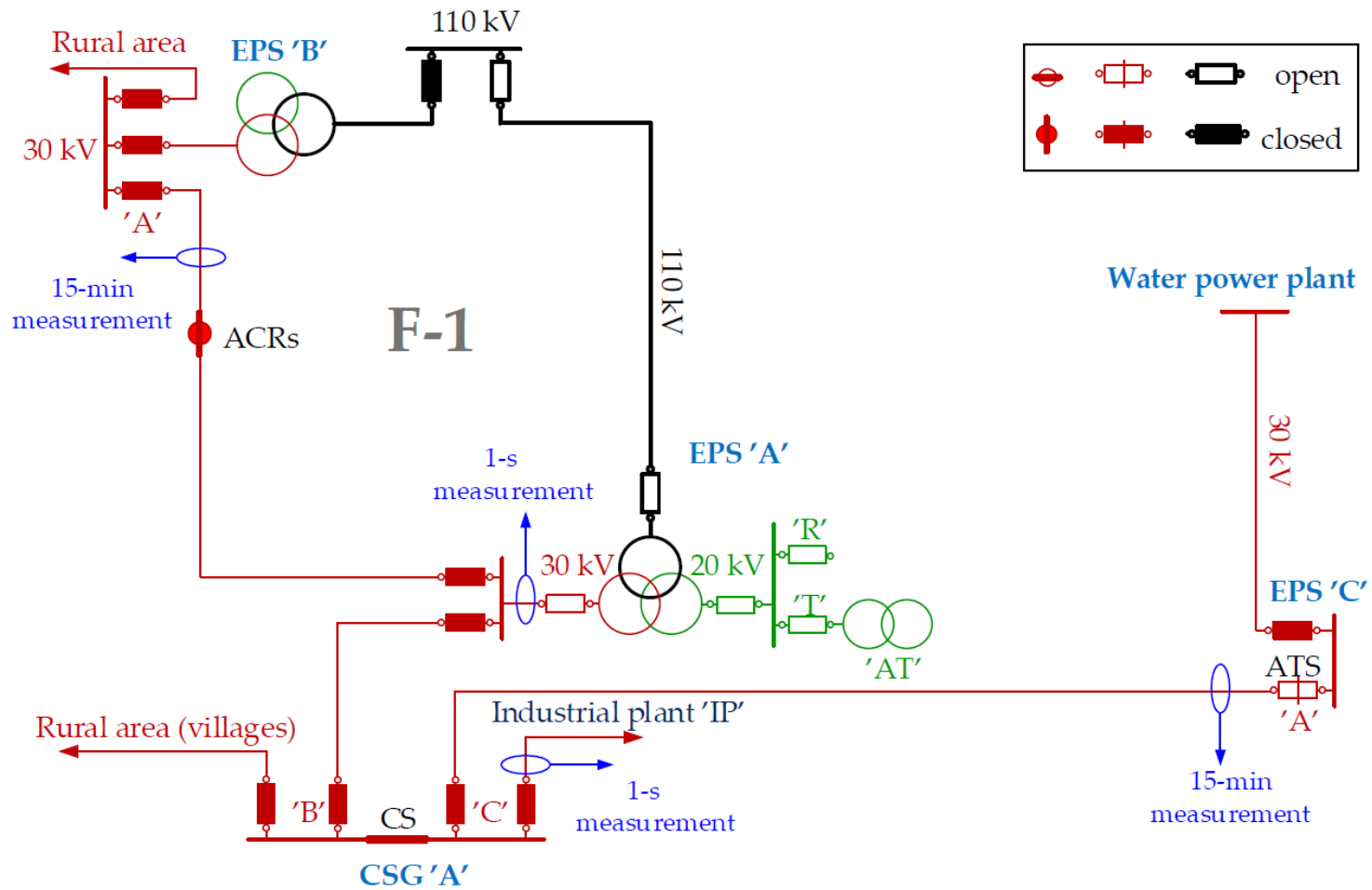

Figure 2. The system structure in the outage condition F-1 in a fail state of a $110 \mathrm{kV}$ line.

The $30 \mathrm{kV}$ line section between EPS " $\mathrm{B}$ " and the ACRs runs in a difficult area; therefore, it is exposed to increased failure rate. The one-year data contained in Table 3 are obtained from the local DSO.

Table 3. Events list in MV $30 \mathrm{kV}$ lines between EPS “B” and automatic circuit reclosers (ACRs).

\begin{tabular}{cc}
\hline The Problems & Number of Events \\
\hline Failure & 12 \\
\hline $\begin{array}{c}\text { Disturbances; activation of automatic reconnection breakers } \\
\text { (ARC) }\end{array}$ & 13 \\
\hline
\end{tabular}

In the event of a parallel failure of the $110 \mathrm{kV}$ and $30 \mathrm{kV}$ line between EPS " $\mathrm{B}$ " and EPS " $\mathrm{A}$ ", the network switches to the F-2 operating condition (Figure 3). In this condition, the considered distribution area of the network remains without power. 


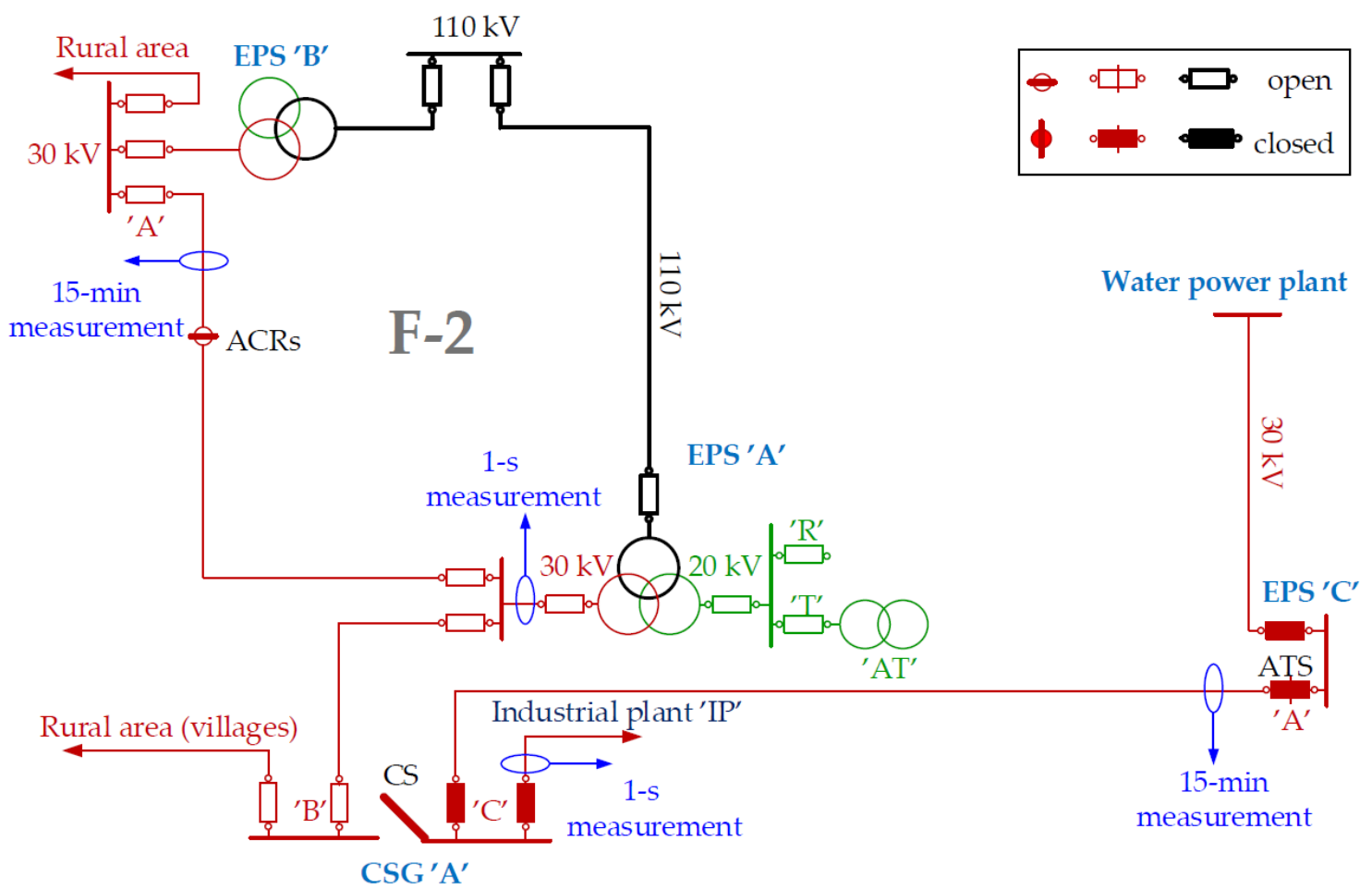

Figure 3. The system structure in the outage condition F-2 in the fail state of a $110 \mathrm{kV}$ and $30 \mathrm{kV}$ line.

The considered distribution network area in the outage condition F-2 with the ESS implemented into EPS " $\mathrm{A}$ " (Figure 5) and after appropriate reconfiguration of the $30 \mathrm{kV}$ network can work as an island operation condition F-2* (Figure 4).

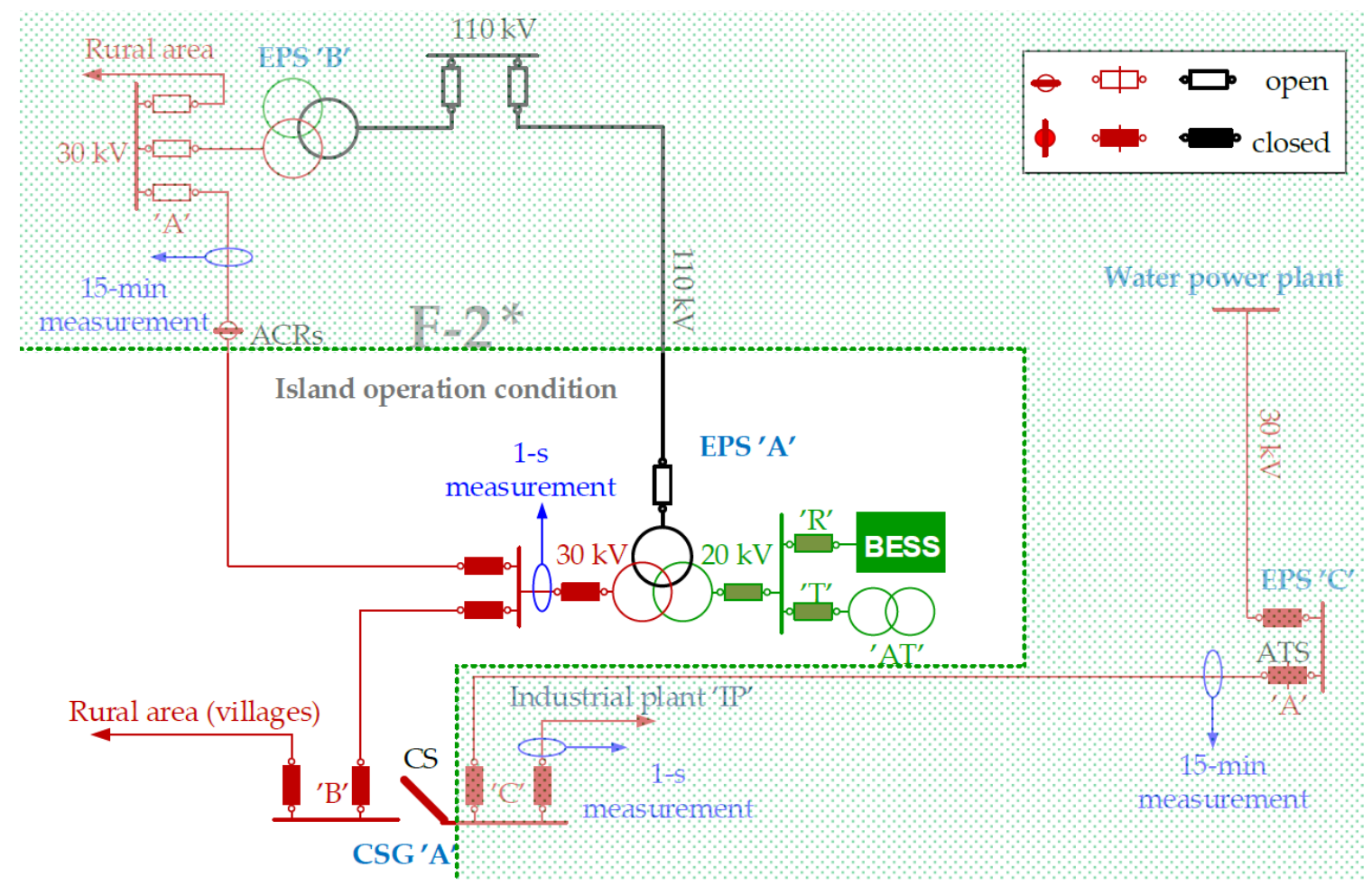

Figure 4. The system structure in the island operation condition F-2*. 
In the island operation condition $\mathbf{F}-2^{*}$, the BESS is connected to the reserve linear field " $R$ " in the switchgear of the substation EPS " $A$ ". The first place of the network division is the ACR, while the second is CS in the CSG " $\mathrm{A}$ ".

Due to the limited load capacity of the network from the EPS " $C$ " substation side, resulting from voltage conditions, in the operation condition F-2 and F-2*, the "IP" factory operates with a power limited to 1.2 MVA (during normal operation-1.82 MVA).

\subsection{Operating Status of Switches in All Operation Conditions}

The operating statuses of switches in the described network of all operating conditions are presented in Table 4.

Table 4. Operating statuses of switches.

\begin{tabular}{|c|c|c|c|c|c|c|}
\hline Layout & $\begin{array}{c}110 \mathrm{kV} \\
\text { “B”-“A” }\end{array}$ & $\begin{array}{c}30 \mathrm{kV} \\
\text { “B”-“A” }\end{array}$ & ACRs & $\begin{array}{c}\mathrm{CSG} \text { "A" } \\
\mathrm{CS}\end{array}$ & $\begin{array}{l}\text { EPS “C” } \\
\text { ATS “A" }\end{array}$ & BESS \\
\hline $\mathrm{N}$ & ON & ON & OFF & OFF & OFF & OFF \\
\hline F-1 & OFF & ON & ON & OFF & OFF & OFF \\
\hline F-2 & OFF & OFF & OFF & $\mathrm{ON}$ & ON & OFF \\
\hline F-2* & OFF & OFF & OFF & ON & ON & ON \\
\hline
\end{tabular}

F-2*-F-2 with BESS and island operation.

\section{Parameter Determination of the Energy Storage System}

The predicted connection point for the energy storage system (Figure 5) is a $20 \mathrm{kV}$ switchgear implemented into EPS "A" substation (see Figure 4). The main components of the ESS are: an energy storage (ES) with a battery management system (BMS); a bidirectional converter with an input $\left(\mathrm{F}_{\text {in }}\right)$ and output $\left(\mathrm{F}_{\text {out }}\right)$ filter as a power conversion system (PCS); and an MV/LV coupling transformer. The master controller (Supervisory Control And Data Acquisition-SCADA) includes the function of supervision over the course of the entire process.

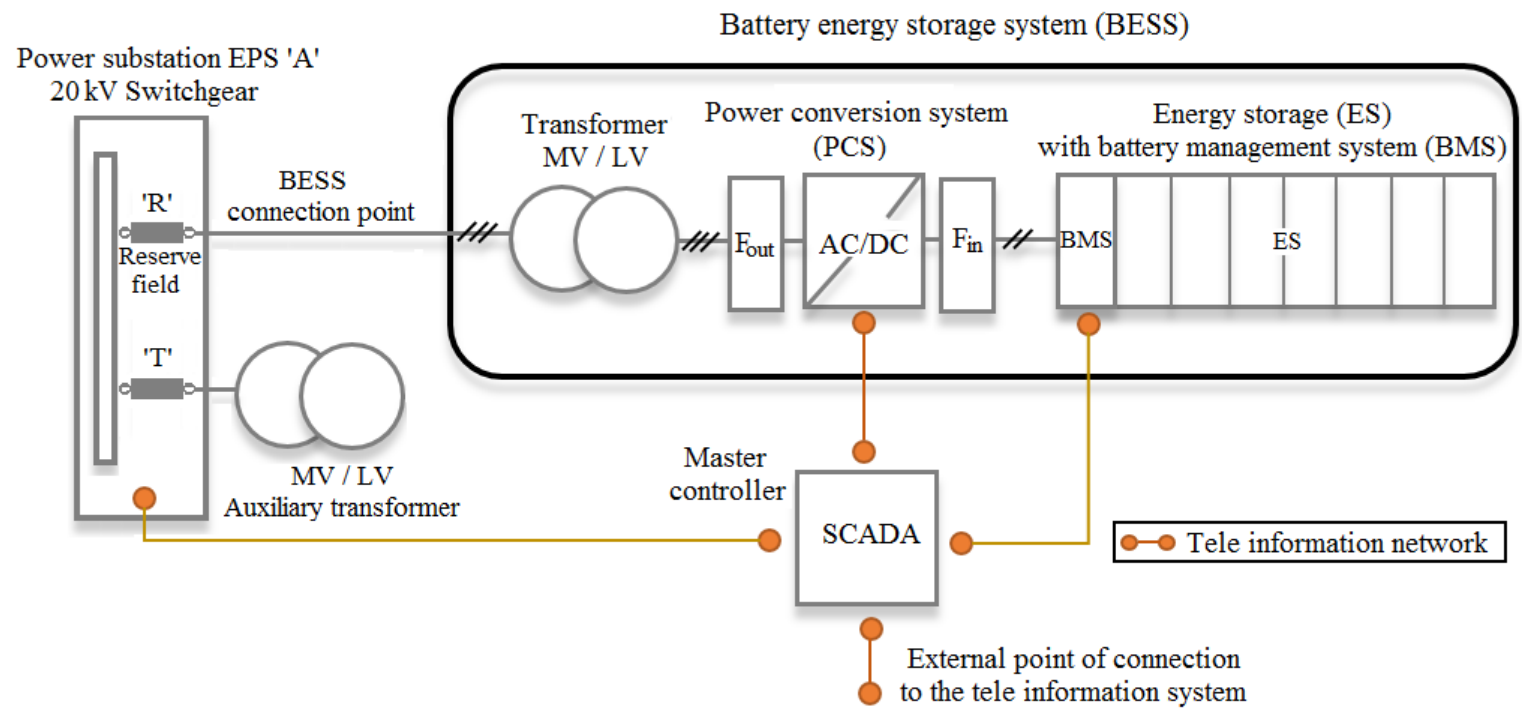

Figure 5. Simplified structure of the BESS.

In order to select the parameters of the energy storage system for the separated network area with the possibility of island operation, it is necessary to determine the energy profile of the network section based on real 2-week measurement data made in the operating condition N. Based on this data, we have to determine the ESS parameters. Then, we should review and select energy storage technologies. Having determined ESS 
parameters and technology, the considered network should be reanalysed in all operating conditions. A simplified flow chart of the steps for defining the parameters and technology of the ESS is shown in Figure 6.

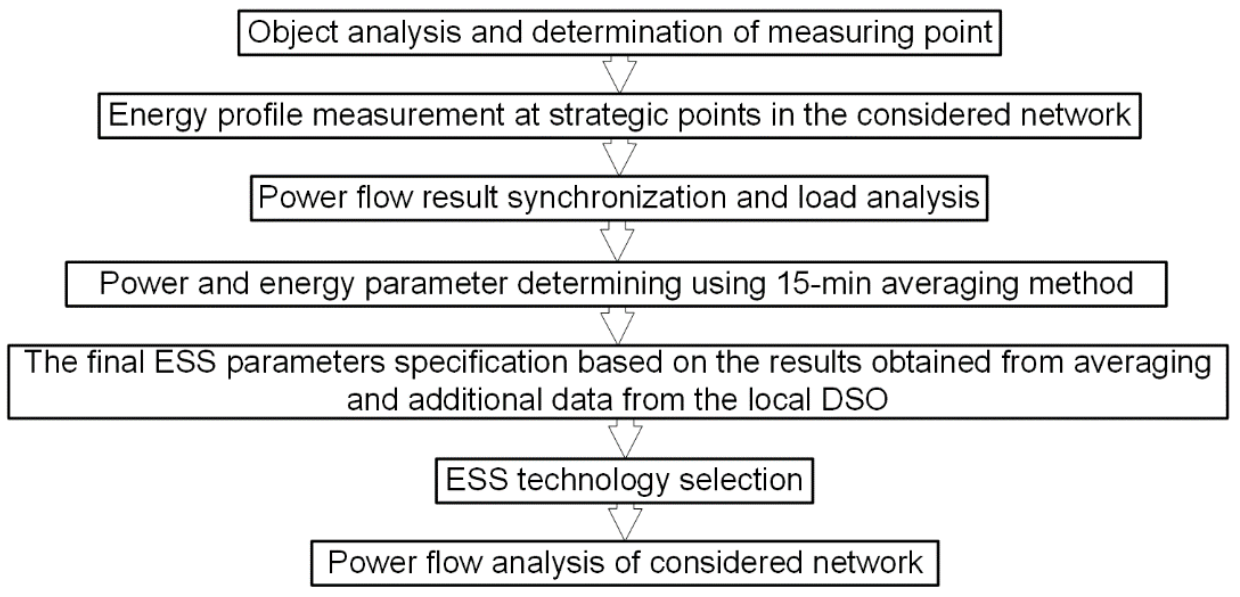

Figure 6. Simplified flow chart of the ESS selection.

3.1. Power and Energy Profile Measurement and Analysis Using the 15-min Averaging Method

The object analysis allows the determination of appropriate measurement points. After an objective analysis of the system of considered network connections, along with the construction of individual substations, the two most important measurement points (1 s measurement) were selected, and they are:

- $\quad 30 \mathrm{kV}$ main power bus in substation EPS "A" (Figure 1);

- Line field in CSG " $\mathrm{A}$ " in substation EPS " $\mathrm{A}$ ", connected to which is a large recipient, the industrial plant "IP" (Figure 1).

The real measurement data from those two points will allow us to calculate the right value of power and energy of the ES. Based on the information of the power flow data from previous years, obtained from the local DSO, the flow of active power average $P_{\text {avg(1-s) }}$ was measured in a 2-week summer period, with the highest expected load capacity.

For measurements, the Fluke 437 Series II power quality and electricity analyser was used. The analysis of the real measurement data $\left(P_{\mathrm{avg}(1-\mathrm{s})}\right)$ was performed in the RStudio program by using a $15 \mathrm{~min}$ averaging method in accordance with the EN standards $[30,31]$ (concerning the measurement of AC energy flow in a distribution network).

The EN 50470-3 standard [30] defines the particular requirements of static meters for active energy, and the EN 62055-31 standard [31] defines the particular requirements of static payment meters for active energy.

Thus, our method is closely related to the EN standards for the settlement of payments for active energy, and involves the calculation of an average $15 \mathrm{~min}$ active power $P_{\text {avg(15-min) }}$ (1) by overlaying moving average window on the samples $P_{\text {avg(1-s) }}$.

$$
\begin{aligned}
& P_{\operatorname{avg}(15-\min ) 1}(t)=\frac{\sum_{t=1}^{900} P_{\operatorname{avg}(1-s)}(t)}{900} \\
& P_{\operatorname{avg}(15-\min ) 2}(t)=\frac{\sum_{t=2} P_{\operatorname{avg}(1-s)}(t)}{900+(n-1)} P_{\operatorname{avg}(1-s)}(t) \\
& P_{\operatorname{avg}(15-\min ) n}(t)=\frac{\sum_{t=n} 900}{900}
\end{aligned}
$$

where $1 ; 2 ; \mathrm{n}$ are consecutive overlaying 15 min moving average windows on the $1 \mathrm{~s}$ power samples $P_{\text {avg(1-s) }}$. The number 900 represents the number of 1 s power samples $P_{\text {avg }(1-\mathrm{s})}$ of one time windows, but also $900 \mathrm{~s}$, or $15 \mathrm{~min}$. 
Hourly average energy values $E_{\operatorname{avg}(1 \mathrm{~h})}, E_{\mathrm{avg}(1.5 \mathrm{~h})}, E_{\mathrm{avg}(2 \mathrm{~h})}$ were calculated based on the average power $P_{\text {avg }}$ in the same averaging window (2).

$$
E_{\text {avg }}\left(t_{0}, t\right)=\int_{t_{0}}^{t} P_{a v g(15-\min )}(d t),
$$

where $t$ is the energy demand time, for example, $t=1.0 ; 1.5$ or $2.0 \mathrm{~h}$.

In order to determine the parameters of the energy storage (ES) correctly, we will analyse the nature of active power flow of $P_{\mathrm{EPS}^{\prime \prime} \mathrm{A}}$ and energy $E_{\mathrm{EPS}} \mathrm{A}^{\prime \prime}$. The 2-week period of $P_{\text {EPS"A" }}$ power profile of the EPS "A" substation in the operation condition $\mathrm{N}$ of the considered network is shown in Figure 7.

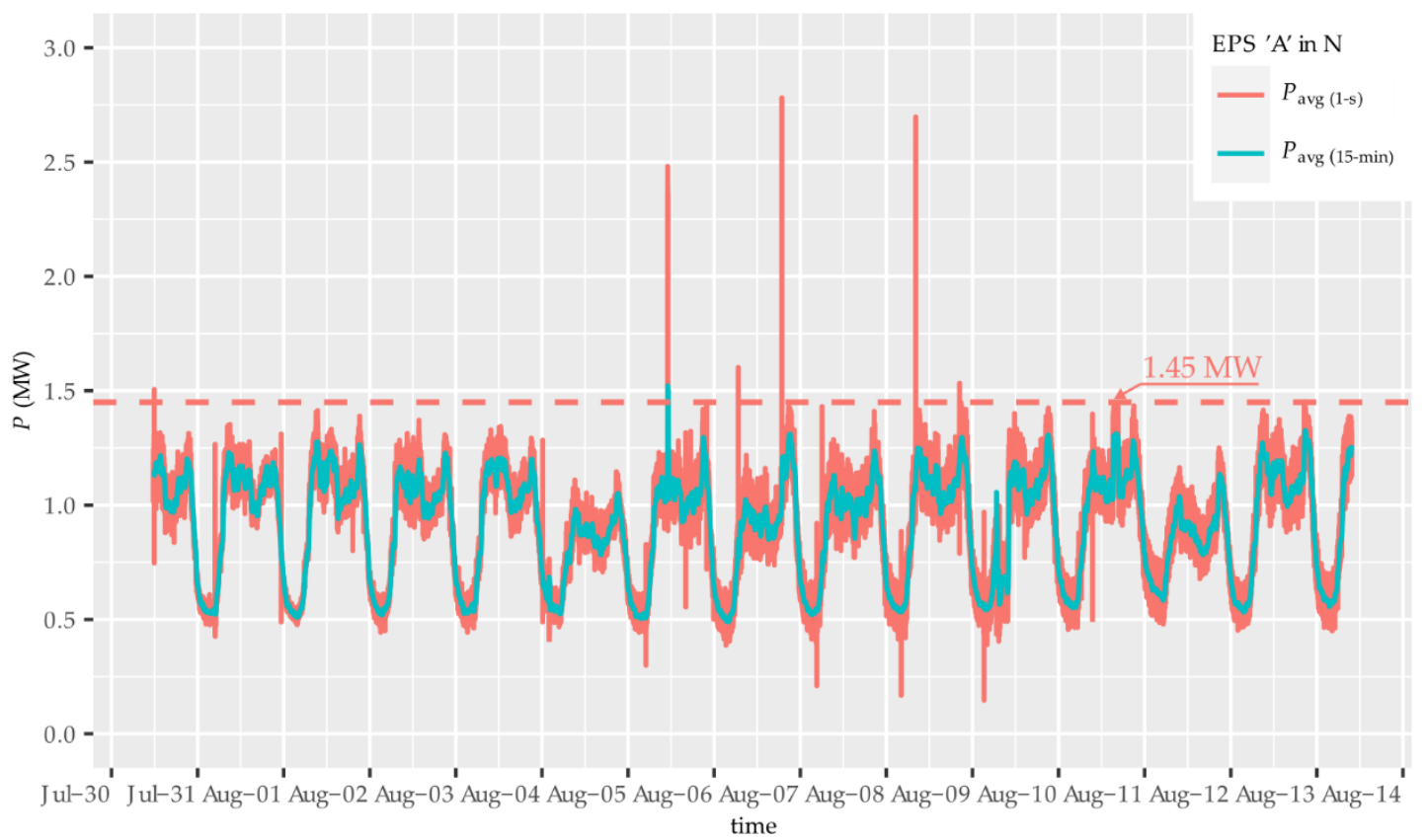

Figure 7. The 2-week period of power flow $P_{\text {EPS"A" }}$ at EPS "A" in the normal operating condition N without "IP".

The 2-week measurement data do not take into account the power consumption of the "IP" industrial plant.

The 2-week period of $E_{\mathrm{EPS}}$ " $\mathrm{A}$ " energy profile of the EPS " $\mathrm{A}$ " substation for selected time intervals in the operation condition $\mathrm{N}$ of network operation is shown in Figure 8.

The maximum values of active power $P_{\max } \mathrm{EPS}^{\prime \prime} \mathrm{A}$ " and energy demand $E_{\mathrm{EPS}} \mathrm{A}^{\prime \prime}$ of the considered EPS " $\mathrm{A}$ " substation in the operation condition $\mathrm{N}$ from the selected 2-week summer period are presented in Table 5 .

Table 5. Active power $P$ and energy $E$ of the considered EPS " $\mathrm{A}$ " in the normal operation $\mathrm{N}$.

\begin{tabular}{cccc}
\hline \multirow{2}{*}{ Available Parameters } & \multicolumn{3}{c}{ Operating Time } \\
\cline { 2 - 4 } & $\mathbf{1 . 0}(\mathbf{h})$ & $\mathbf{1 . 5}(\mathbf{h})$ & $\mathbf{2 . 0}$ (h) \\
\hline$P_{\text {max EPS "A" }}(\mathrm{MW})$ & & 1.45 \\
\hline$E_{\mathrm{EPS}}$ "A" $(\mathrm{MWh})$ & 1.29 & 1.93 & 2.53 \\
\hline$C_{\text {rate }}(1 / \mathrm{h})$ & 1.13 & 0.75 & 0.57 \\
\hline
\end{tabular}




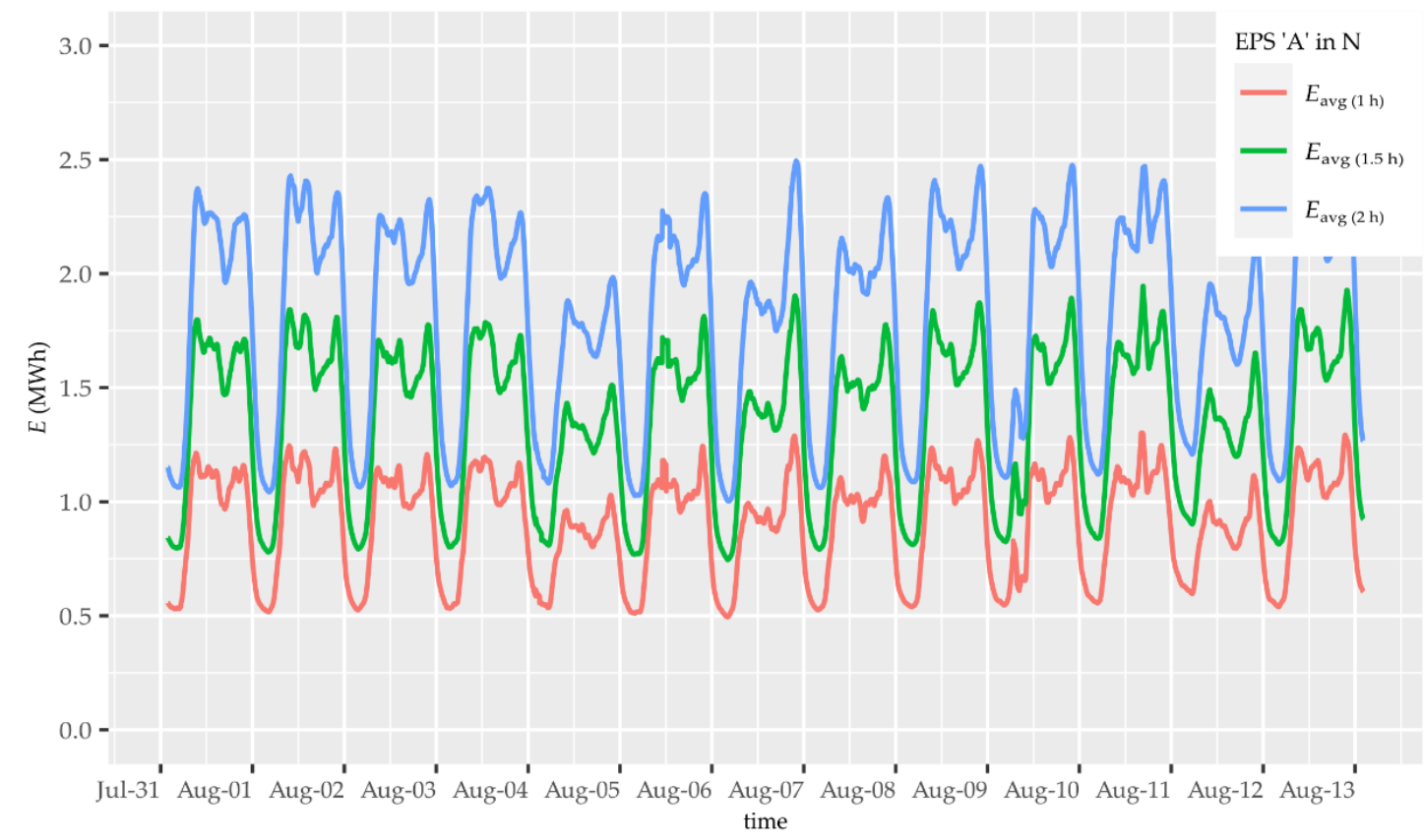

Figure 8. The 2-week period of energy flow $E_{\mathrm{EPS}} \mathrm{A}$ " consumption at EPS " $\mathrm{A}$ " in the normal operating condition $\mathrm{N}$ without "IP".

\subsection{Parameter Determination for Energy Storage System}

Accounting for the fact that the data presented in Table 5 refer to the selected 2-week power in the summer period, $6-7 \%$ of the increased network load in the winter period should be added to them.

Figure 9 shows a comparison of the 1-day power profile of the selected winter day with the highest network load for a selected summer day.

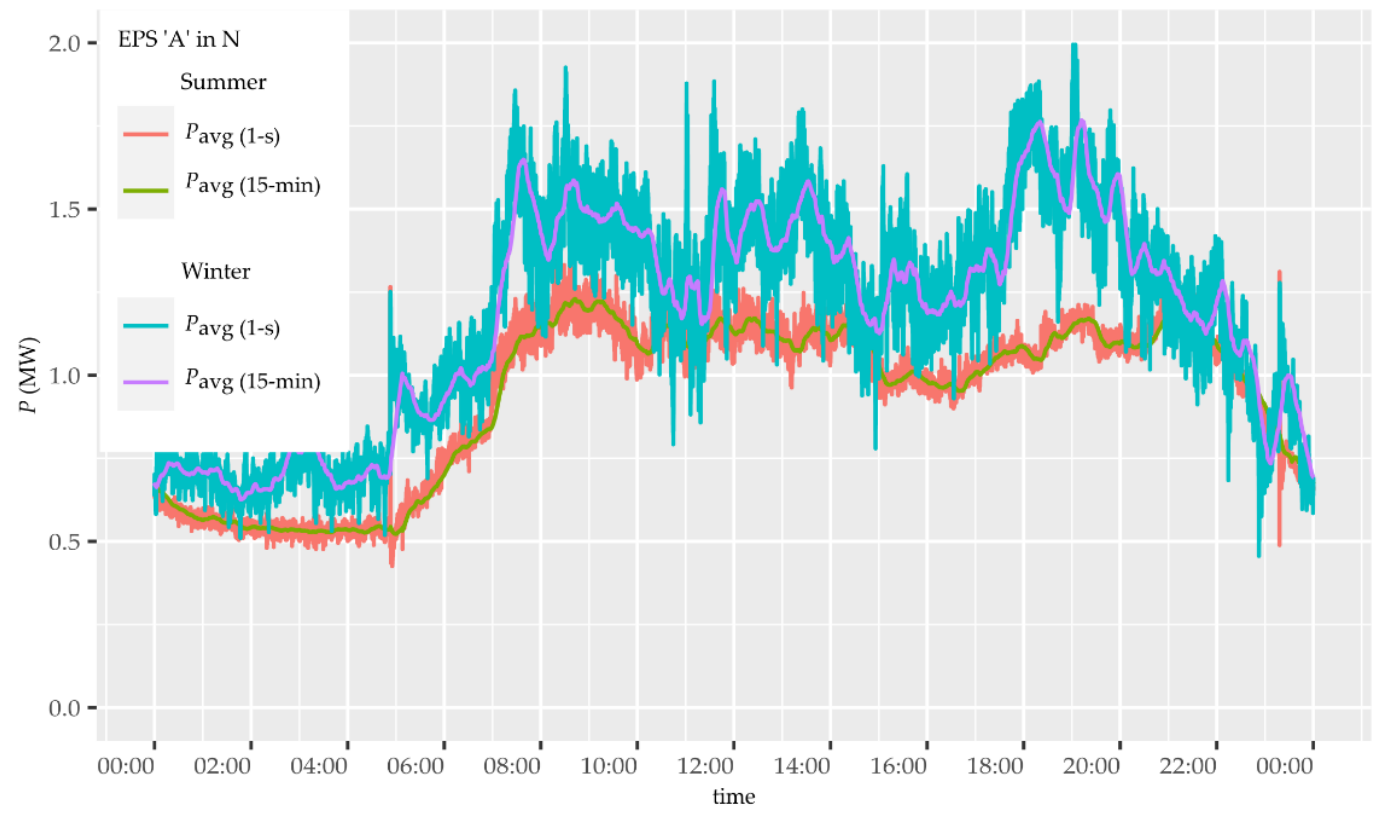

Figure 9. The 1-day winter and summer period of power flow $P$ at EPS "A" in normal operating condition N without "IP".

Based on the information obtained from the local DSO, to account for the increased demand for energy in the winter, we have to add a $15 \%$ increase in the network load due to 
the planned expansion of the considered power system. The corrected values of power $P$ and energy demand $E$ for the correct determination of the energy storage (ES) parameters are presented in Table 6 .

Table 6. Power $P_{\mathrm{ES}}$ and energy $E_{\mathrm{ES}}$ of energy storage.

\begin{tabular}{cccc}
\hline & \multicolumn{3}{c}{ ES Operating Time } \\
\cline { 2 - 4 } Available Parameters & $\mathbf{1 . 0}$ (h) & $\mathbf{1 . 5}$ (h) & $\mathbf{2 . 0}$ (h) \\
\hline$P_{\text {max EPS “A” }}(\mathrm{MW})$ & 1.58 & $\mathbf{1 . 7 8}$ \\
\hline$E_{\text {EPS "A" }}(\mathrm{MWh})$ & 1.13 & 0.75 & 3.11 \\
\hline$C_{\text {rate }}(1 / \mathrm{h})$ & &
\end{tabular}

In order to determine the parameters of the transformer (TR) and power conversion system (PCS), we will analyse the apparent power $S$. The $S$ power can be represented by a dependency:

$$
S=\frac{P}{\cos \varphi} .
$$

According to the EN 50160 standard, it is permissible to operate the electrical network with a power factor (PF) not higher than $0.4(\operatorname{tg} \varphi=0.4 \rightarrow \cos \varphi=0.93)$. In addition, we took into account the extra reactive power $Q$ resulting from the fact that part of the supplied area is on the $30 \mathrm{kV}$ side of a three-winding transformer of EPS " $\mathrm{A}$ ". In the $\mathbf{F}-\mathbf{2}^{*}$ configuration, the loading on the transformer will be quite low $(10 \%$ with fairly equal sharing on the $20 \mathrm{kV}$ and $30 \mathrm{kV}$ side).

Finally, when selecting the $S$ power, we assumed $\cos \varphi=0.9$, which gave the value of this power at approximately 1.98 MVA, rounded to the typical value 2 MVA from the series of devices used. The parameters of the ESS determined on the basis of measurements and corrected on the basis of data received from the local DSO are presented in Table 7.

Table 7. Parameters of the ESS.

\begin{tabular}{ccc}
\hline Available Parameters & Corrected Value & Comments \\
\hline$S_{\mathrm{TR}}[\mathrm{MVA}]$ & 2.00 & $\begin{array}{c}\text { Additional reactive power } Q \\
\text { is taken into account }\end{array}$ \\
\hline$S_{\mathrm{PCS}}[\mathrm{MVA}]$ & 2.00 & Minimum power \\
\hline$P_{\mathrm{ES}}[\mathrm{MW}]$ & 1.78 & $* * *$ Operation time-1.5 $[\mathrm{h}]$ \\
\hline$E_{\mathrm{ES}}[\mathrm{MWh}]$ & 2.37 &
\end{tabular}

\subsection{Technology Selection of the Energy Storage}

In order to guarantee the available parameters, energy storage (ES) devices made in most technologies must be oversized to the value of the so-called "Corrected Energy", depending on the required parameters and operating conditions of a given reservoir. Taking into account the $C_{\text {rate }}$ coefficient presented in Table 6, virtually any of the energy storage technologies currently available on the market can be implemented at the EPS " $\mathrm{A}$ " substation. Selected parameters of most popular energy storage devices made in various technologies are summarized in Table 8. 
Table 8. Selected parameters of ES technology.

\begin{tabular}{|c|c|c|c|c|c|c|}
\hline \multirow{2}{*}{ Parameter } & \multicolumn{6}{|c|}{ Technology } \\
\hline & EDLC & LIC & RFB * & $\mathrm{LiFePO}_{4}$ & LTO & NMC \\
\hline Service life (cycle) & $>1$ million & $>1$ million & $<5000$ & $<6000$ & $<30,000$ & $<6000$ \\
\hline$C_{\text {rate }(-) \text { _tech }}(1 / \mathrm{h})$ & $>100 \mathrm{C}$ & $>30 \mathrm{C}$ & $<0.5$ & $<3 C$ & $<15 \mathrm{C}$ & $<3 C$ \\
\hline$C_{\text {rate }(+) \_t e c h}(1 / \mathrm{h})$ & $>100 \mathrm{C}$ & $>30 \mathrm{C}$ & $<0.5$ & $<1 C$ & $<5 \mathrm{C}$ & $<1 C$ \\
\hline $\operatorname{DoD}(\%)$ & $<75$ & $<100$ & 100 & $<80$ & $<80$ & $<80$ \\
\hline$\eta(\%)$ & $<96$ & $<96$ & $<85$ & $<96$ & $<96$ & $<96$ \\
\hline$K_{\mathrm{V}}(\mathrm{Wh} / \mathrm{l})$ & 3.5 & 7.5 & 3.5 & 160 & 80 & 208 \\
\hline$K_{\mathrm{m}}(\mathrm{Wh} / \mathrm{kg})$ & 3.3 & 9.5 & 40 & 100 & 45 & 150 \\
\hline CAPEX $X_{\text {tech }}(\mathrm{EUR} / \mathrm{kWh})$ & 43,182 & 39,773 & 614 & 364 & 864 & 295 \\
\hline
\end{tabular}

EDLC-electrostatic double-layer capacitor; LIC-lithium-ion capacitor; RFB-redox flow battery $\left({ }^{*} \mathrm{ZnBr}\right) ; \mathrm{LiFePO}_{4}$-lithium iron phosphate battery; LTO—lithium-titanate battery; NMC—nickel manganese cobalt battery; CAPEX - capital expenditures.

Assuming that the ESS will work occasionally as a backup power source for the EPS " $\mathrm{A}$ " substation, the life cycles criterion will be met by most of the available technologies and will not be the main criterion for the storage technology selection. When choosing a technology, one should be guided by the investment cost CAPEX (capital expenditures) and possible location and sizing limitations. The supercapacitor types electrostatic double-layer capacitor (EDLC) and lithium-ion capacitor (LIC) are characterized by very high life cycles ( $>1$ million) and a very high charge discharge ratio $\left(C_{\text {rate }}>100\right.$ for EDLC and $C_{\text {rate }}>30$ for LIC), but they have one of the lowest volumetric energy densities $\left(K_{\mathrm{V}}\right)$ and one of the lowest mass energy densities $\left(K_{\mathrm{m}}\right)$. Moreover, they are characterized by the highest CAPEX. Due to the assumed operating conditions of the ESS (occasional work of proposed system) and the low required $C_{\text {rate }}$ coefficient, not exceeding $1-$ for a $1.5 \mathrm{~h}$ period of operation, the EDLC and LIC technologies will not be taken into account. The redox flow battery (RFB) $(\mathrm{ZnBr})$ technology will also not be taken into account because, similar to the EDLC and LIC technologies, it has a very low volumetric energy density $\left(K_{\mathrm{V}}\right)$ and has the lowest $C_{\text {rate }}$ coefficient $(<0.5)$, which would require an increased investment area for the ESS.

Due to the above, we take into account Li-ion technologies; however, due to the permissible degree of cycle discharge $(D o D)$ when the ESS is implemented in EPS " $\mathrm{A}$ ", ES should be oversized so that, taking into account the maximum value of $D o D$, it would ensure the required usable capacity (Table 9). In summary, we must maintain the following conditions for Li-ion technology:

- Oversizing reduces the risk of discharging the tank below $S o C_{\min }=20 \%$

- Oversizing reduces the degree of cycle discharge of the tank $D o D=S o C_{\max }-S o C_{\min }$, which in turn leads to an increase in the service life of the tank;

- $S o C_{\max }$ is a relative-limited value maximum $S o C_{\mathrm{n}}$ nominal value of the storage and, for lithium technology, is typical: $S_{0} C_{\max } \leq 90-95 \% S o C_{n}$.

Taking into account the estimated parameters, lithium ferrophosphate (LFP) $\left(\mathrm{LiFePO}_{4}\right)$ and nickel manganese cobalt battery (NMC) technology are recommended for implementation for BESS at EPS "A". Lithium-titanate battery (LTO) technology is economically unjustified due to the high investment cost CAPEX. 
Table 9. Adjusted parameters and estimated ES investment cost $C A P E X_{\mathrm{ES}}$ depending on the storage technology.

\begin{tabular}{lccc}
\hline \multirow{2}{*}{ Parameter } & \multicolumn{2}{c}{ Technology } \\
\cline { 2 - 4 } & $\mathbf{L i F e P O}_{4}$ & LTO & NMC \\
\hline$P_{\text {ES }}(\mathrm{MW})$ & & $\mathbf{1 . 7 8}$ & \\
\hline$E_{\mathrm{ES}}(1.5 \mathrm{~h})$ & $(\mathrm{MWh})$ & 2.37 & $\mathbf{1}$ \\
\hline Adjusted energy $(\mathrm{MWh})$ & $\mathbf{1}$ & $\mathbf{2 . 9 6}$ & $\mathbf{0 . 8 7 5}$ \\
\hline$C_{\text {rate_tech }}(1 / \mathrm{h})$ & $\mathbf{1 . 0 8 0}$ & 2.560 & \\
\hline CAPEX & & 5 & \\
\hline Comments & (million EUR) & $*$ large space required; high investment cost \\
\hline
\end{tabular}

\subsection{Spatial Analysis of the Energy Storage Provided for EPS " $A$ "}

Let us analyse the space and mass ES requirements in relation to the $K_{\mathrm{V}}$ and $K_{\mathrm{m}}$ parameters (Table 8 ) on the basis of power, energy capacity and technology. Parameters of the sea containers type 1C (standard 20 feet) and 1A (standard 40 feet) are presented in Table 10.

Table 10. Parameters of containers.

\begin{tabular}{cccccc}
\hline Type & $\begin{array}{c}\text { Internal } \\
\text { Length } \\
(\mathbf{m m})\end{array}$ & $\begin{array}{c}\text { Internal } \\
\text { Width } \\
\mathbf{( m m )}\end{array}$ & $\begin{array}{c}\text { Internal } \\
\text { High } \\
\mathbf{( m m )}\end{array}$ & $\begin{array}{c}\text { Own/Max } \\
\text { Weight } \\
\mathbf{( t )}\end{array}$ & $\begin{array}{c}\text { Internal } \\
\text { Volume } \\
\mathbf{( m}^{\mathbf{3}} \mathbf{)}\end{array}$ \\
\hline $1 \mathrm{C}$ & 5897 & 2330 & 2197 & $2 / 20.32$ & 30 \\
\hline $1 \mathrm{~A}$ & 11,998 & 2330 & 2197 & $3 / 30.48$ & 61.4 \\
\hline
\end{tabular}

If an AC/DC coupling converter PCS (Table 11) is placed into a container, the space requirements of the accumulator and converter should be estimated together in one container.

Table 11. Required assembly parameters of the AC/DC converter.

\begin{tabular}{|c|c|c|c|c|}
\hline $\begin{array}{l}\text { Output } \\
\text { Power } \\
\text { (MVA) }\end{array}$ & $\begin{array}{c}\text { Modules } \\
\text { Quantity } \\
(P+K)\end{array}$ & $\begin{array}{l}\text { External Dimensions } \\
\quad(\mathrm{W} \times \mathrm{D} \times \mathrm{H}) \\
(\mathrm{m} \times \mathrm{m} \times \mathrm{m})\end{array}$ & $\begin{array}{l}\text { Total Volume } \\
\qquad\left(\mathrm{m}^{3}\right)\end{array}$ & $\begin{array}{c}\text { Total Weight } \\
\text { (t) }\end{array}$ \\
\hline 2 & $7 \mathrm{P}+4 \mathrm{~K}$ & $8 \times 0.6 \times 2.25$ & 10.8 & 4.48 \\
\hline
\end{tabular}

Table 12 shows the quantity of containers with regard to the total volume of cells and the converter. The installation space of the $1 \mathrm{~A}$ container was taken into account, assuming that for the Li-ion technology, the available installation space is approximately $50 \%$ of the container volume.

Table 12. Space requirements for the energy storage.

\begin{tabular}{|c|c|c|c|c|}
\hline $\begin{array}{l}\text { Power } \\
\text { (MW) }\end{array}$ & $\begin{array}{l}\text { Energy } \\
\text { (MWh) }\end{array}$ & Technology & $\begin{array}{c}\text { Adjusted Energy } \\
\text { (MWh) }\end{array}$ & $\begin{array}{l}\text { Volume } \\
\left(\mathrm{m}^{3}\right)\end{array}$ \\
\hline \multirow{2}{*}{1.78} & \multirow{2}{*}{2.37} & $\mathrm{LiFePO}_{4}$ & \multirow{2}{*}{2.96} & $29.3(1 \times 1 \mathrm{~A})$ \\
\hline & & NMC & & $25.1(1 \times 1 \mathrm{~A})$ \\
\hline
\end{tabular}

The quantity of containers is equal to the value given in brackets ().

Table 13 shows the quantity of containers with regard to the total weight of the container, cells and the converter. 
Table 13. Load-bearing requirement capacity of container structures.

\begin{tabular}{ccccc}
\hline \multirow{2}{*}{$\begin{array}{c}\text { Power } \\
(\mathbf{M W})\end{array}$} & $\begin{array}{c}\text { Energy } \\
\mathbf{( M W h}\end{array}$ & Technology & $\begin{array}{c}\text { Adjusted Energy } \\
\mathbf{( M W h}\end{array}$ & $\begin{array}{c}\text { Weight } \\
\mathbf{( t )}\end{array}$ \\
\cline { 1 - 3 } 1.78 & 2.37 & $\mathrm{LiFePO}_{4}$ & 2.96 & $34.1(2 \times 1 \mathrm{~A})$ \\
\cline { 2 - 3 } & & $\mathrm{NMC}$ & & $18.7(1 \times 1 \mathrm{~A})$ \\
\hline
\end{tabular}

The quantity of containers is equal to the value given in brackets ().

With reference to Tables 12 and 13, the installation of energy storage in the $\mathrm{LiFePO}_{4}$ technology with PCS converters requires the use of at least two 40 -foot containers $(2 \times 1 \mathrm{~A})$, while the NMC technology requires the use of one 40 -foot container $(1 \times 1 \mathrm{~A})$, but the use of NMC technology requires a more effective fire system.

Table 14 shows the external dimension of an exemplary embodiment of a 2 MVA distribution transformer.

Table 14. Space requirements for a coupling transformer.

\begin{tabular}{cccc}
\hline $\begin{array}{c}\text { Power } \\
(\mathbf{M W})\end{array}$ & $\begin{array}{c}\text { Quantity of } \\
\text { Transformers }\end{array}$ & $\begin{array}{c}\text { Total Surface } \\
\mathbf{( \mathbf { m } ^ { \mathbf { 2 } } )}\end{array}$ & $\begin{array}{c}\text { Total Volume } \\
\left(\mathbf{m}^{\mathbf{3}} \mathbf{)}\right.\end{array}$ \\
\hline 1.78 & $1(2 \mathrm{MVA})$ & $\sim 4.5$ & $\sim 5.1$ \\
\hline
\end{tabular}

\section{Power Flow Analysis and Summary}

The 2-week period of power flow analysis in all the operating conditions of the considered power network is presented in the following figures. Due to the fact that the power factor $P F$ of the tested network reaches favourable parameters, that is, its value is usually higher than $\cos \varphi=0.93$, we will use the apparent power $S$ profile instead of $P$ to simplify and shorten the analyses.

Figure 10 shows the 2-week power flow $S$ of the EPS "B" substation in the operation condition N. In this condition, the substation supplies consumers in a small rural area (see Figure 1).

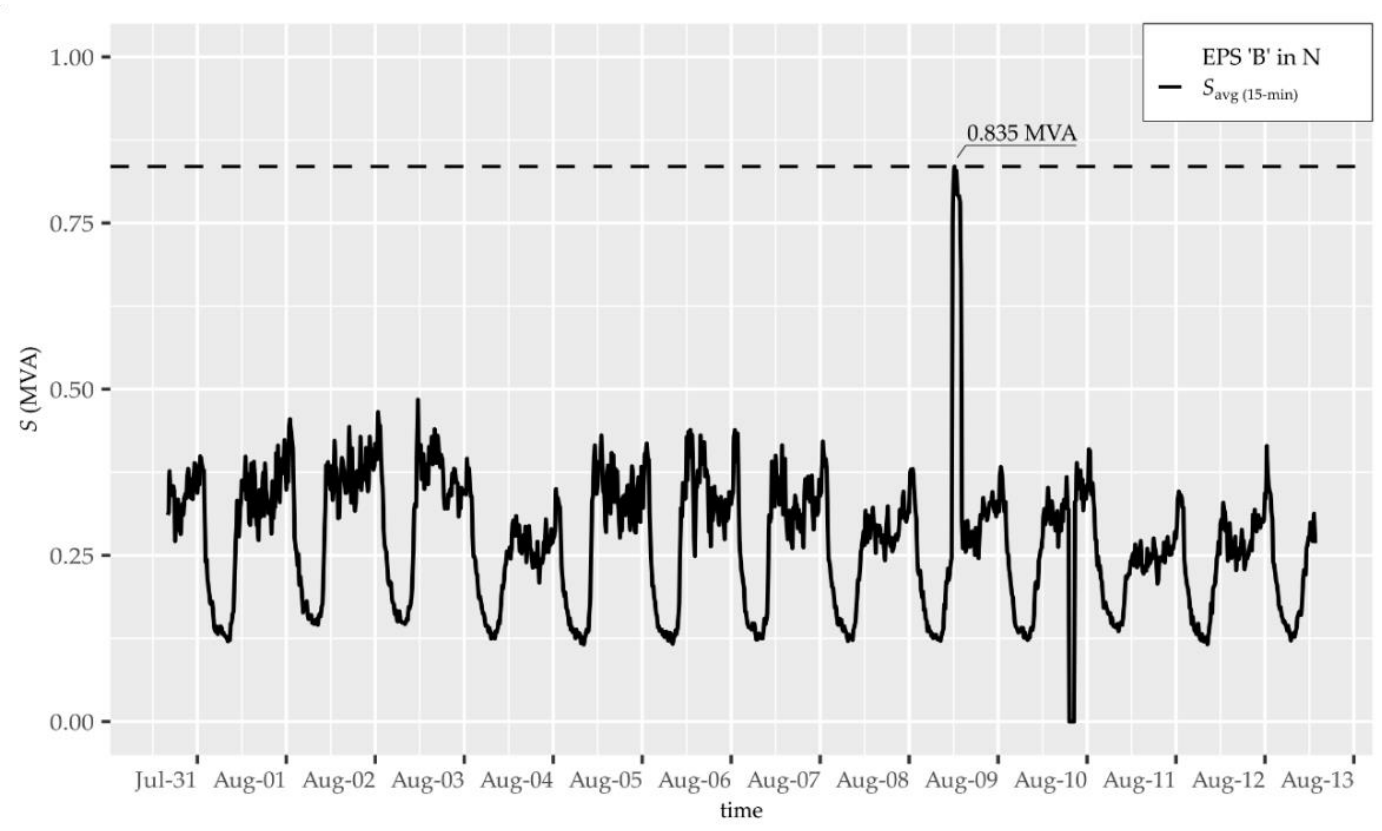

Figure 10. The $S_{\mathrm{EPS}}$ "B" profile of the EPS “B” substation in the normal operating condition N.

Figure 11 shows the 2-week power flow $S$ of the considered substation EPS " $\mathrm{A}$ " in the operation condition $\mathrm{N}$. 


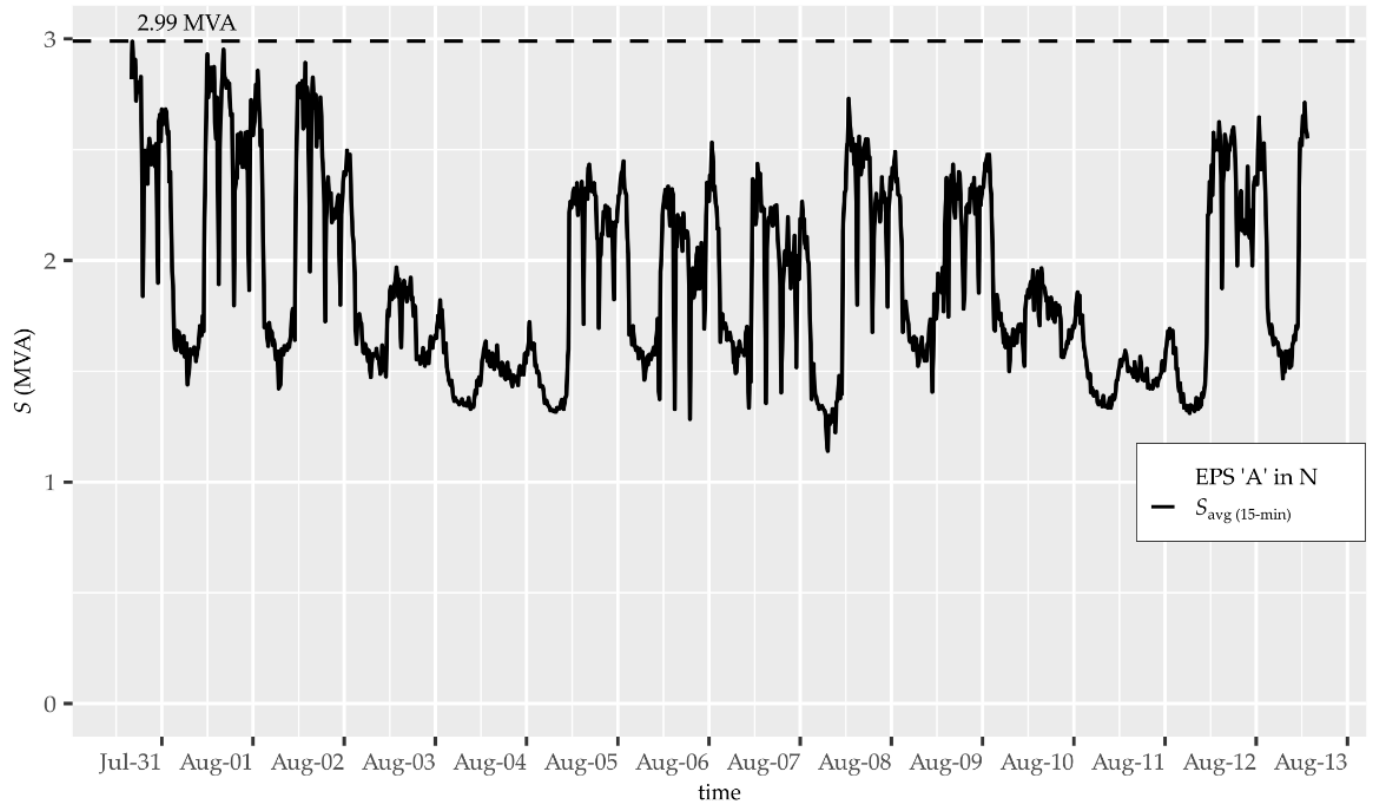

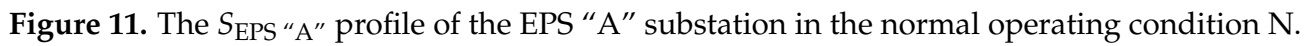

In this condition, the substation supplies energy consumers in a large rural area as well as a single large recipient, the industrial plant "IP" (see Figure 1).

Figure 12 shows the 2-week power flow $S$ of the substation EPS "B" in the failure operating condition F-1. In this condition, the substation supplies all energy recipients in the entire rural area and the large recipient " $\mathrm{IP}^{\prime}$ (see Figure 2). At this time, the power $S$ of the EPS " $\mathrm{A}$ " is $S_{\mathrm{EPS}}$ " $\mathrm{A}$ " $=0$.

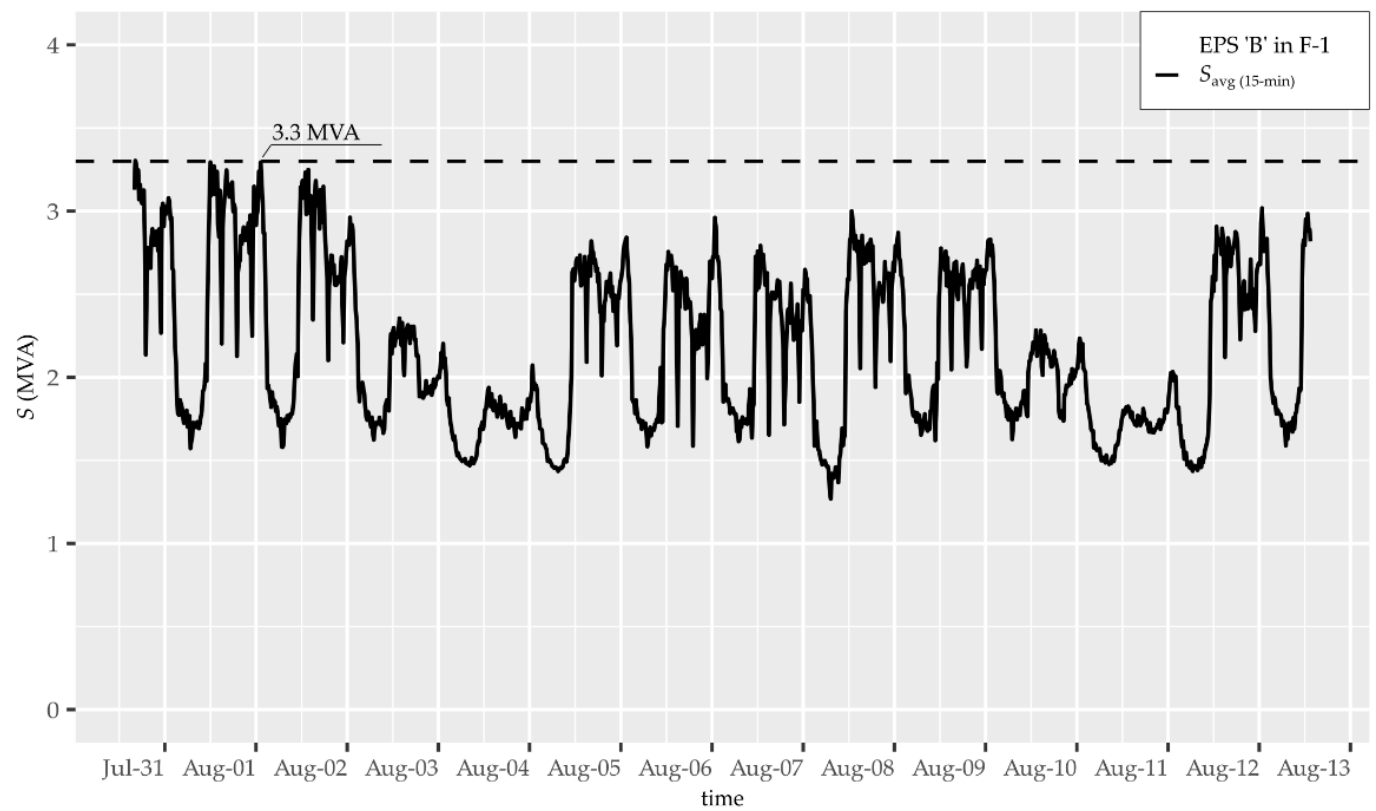

Figure 12. The $S_{\mathrm{EPS}}$ "B" power profile of the EPS “B" substation in the failure operating condition F-1.

Figure 13 shows the 2-week power flow $S$ of the industrial plant "IP" in the operation condition N, F-1 and indicates the power limit to which the recipient must limit themself in the failure operation condition F-2 and island operation F-2* of a considered network. 


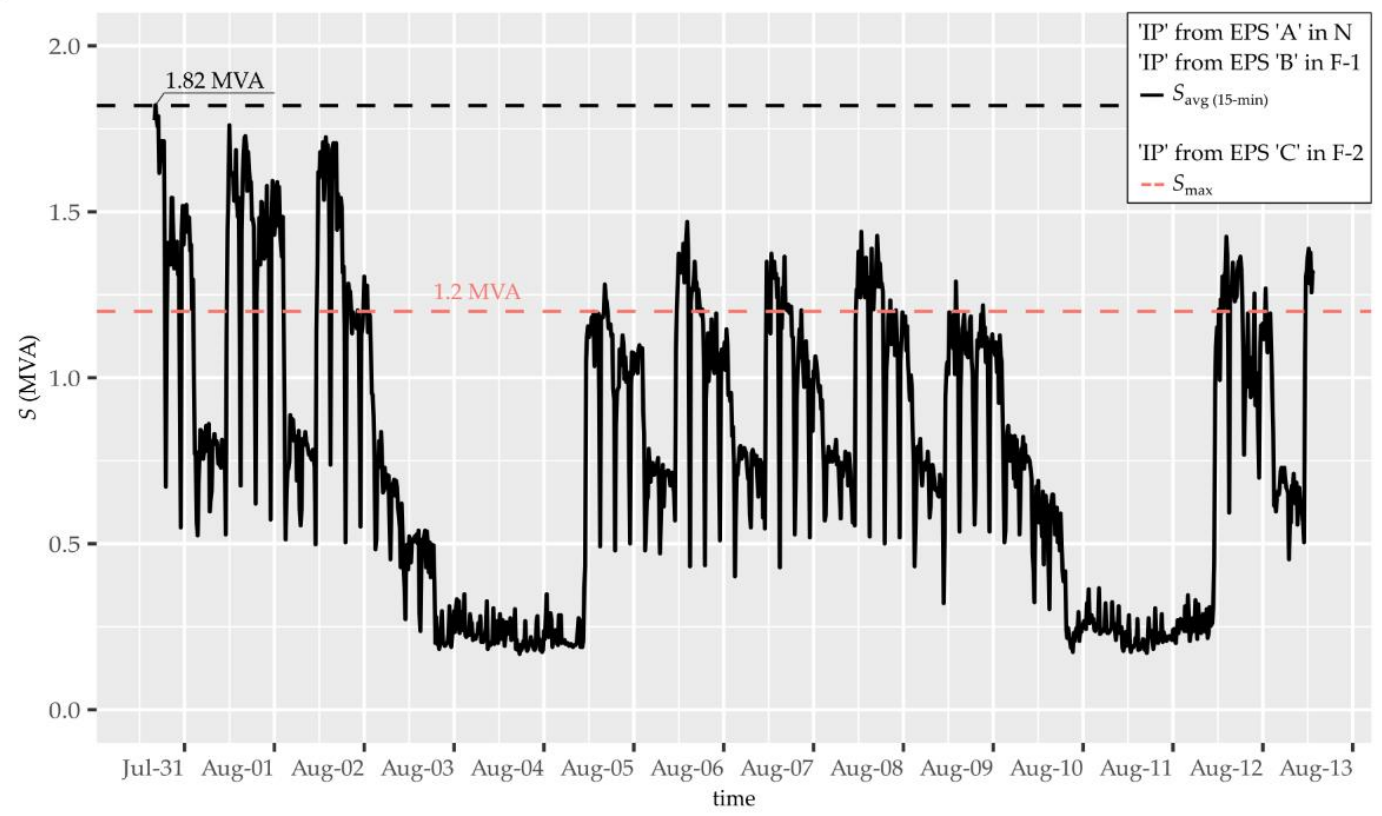

Figure 13. The $S$ "IP" power profile of the industrial plant in the operating condition: N; F-1; F-2; F-2*.

Due to the limited load capacity of the network from the EPS " $\mathrm{C}$ " substation side, resulting from the voltage condition, in the operating conditions F-2 and F-2*, the "IP" factory operates with a power limited to 1.2 MVA (in normal work-1.82 MVA).

Figure 14 shows a 2 -week power flow $S$ of the substation EPS "A" in the island operation condition F-2*. In this condition, the substation supplies energy consumers in a selected, separated rural area (see Figure 4). However, the presented power flow applies to simulation tests, so it should be taken into account that, in this system, the power source will be BESS, and the backup time has been determined at a level not shorter than $1.5 \mathrm{~h}$ with a maximum load of $1.58 \mathrm{MVA}$ (about $1.45 \mathrm{MW}$ ) in the summer.

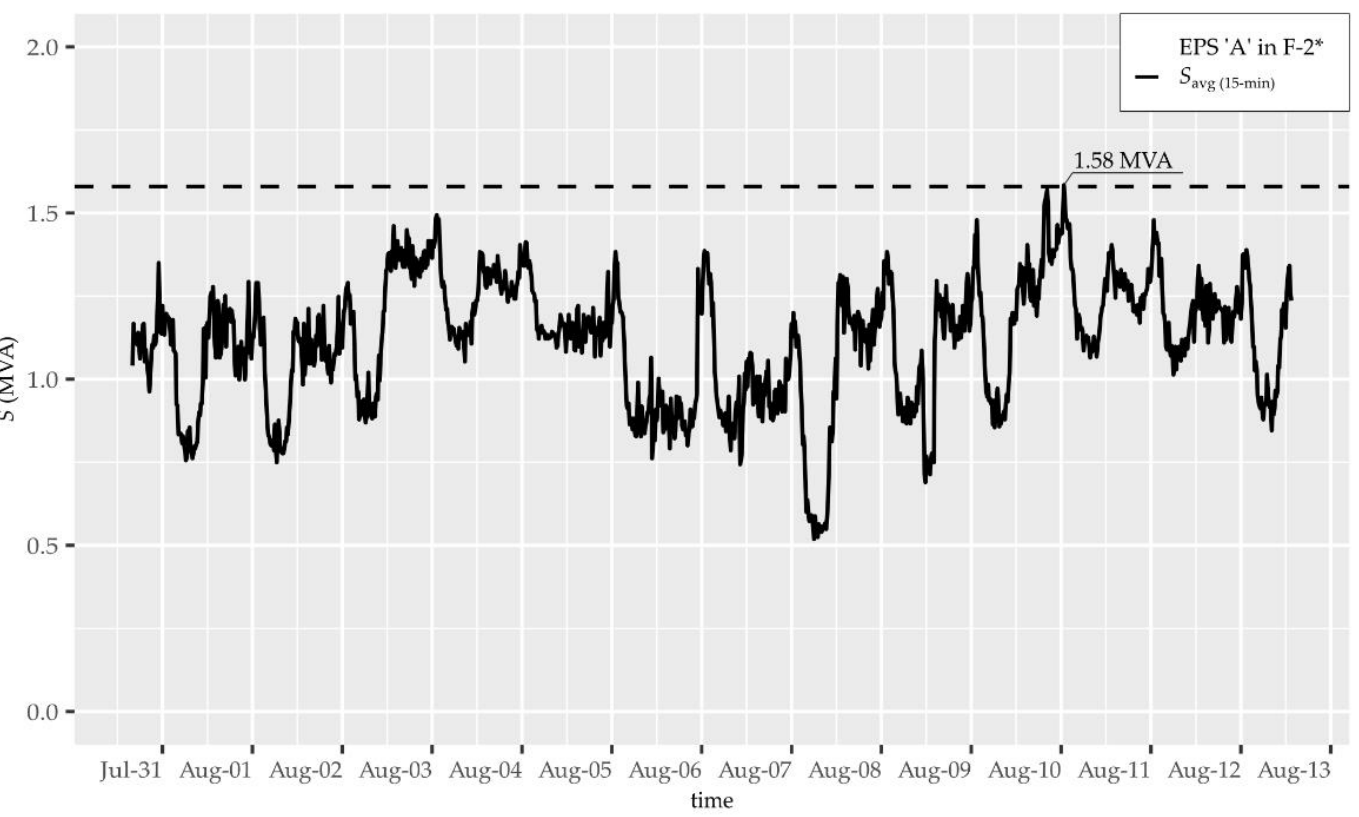

Figure 14. The $S_{\text {EPS }}$ "A" power profile of the EPS "A" substation in the failure operating condition $\mathbf{F}-2^{*}$.

The distribution of the maximum power $S_{\max }$ values in all the operating conditions at selected points of the considered networks is presented in Table 15. 
Table 15. Apparent power $S$ at selected points in the network.

\begin{tabular}{|c|c|c|c|c|}
\hline Layout & $\begin{array}{c}\text { EPS “B” } \\
S_{\max } \text { (MVA) }\end{array}$ & $\begin{array}{c}\text { EPS "A" } \\
S_{\max } \text { (MVA) }\end{array}$ & $\begin{array}{c}\text { "IP" } \\
S_{\max } \text { (MVA) }\end{array}$ & $\begin{array}{c}\text { EPS “C" } \\
S_{\max } \text { (MVA) }\end{array}$ \\
\hline $\mathrm{N}$ & 0.835 (MVA) & 2.99 (MVA) & 1.82 (MVA) & 0 (MVA) \\
\hline $\mathrm{F}-1$ & 3.3 (MVA) & 0 (MVA) & 1.82 (MVA) & 0 (MVA) \\
\hline F-2 & 0 (MVA) & 0 (MVA) & 1.2 (MVA) & 1.2 (MVA) \\
\hline $\mathrm{F}-2^{*}$ & 0 (MVA) & 1.58 (MVA) & 1.2 (MVA) & 1.2 (MVA) \\
\hline
\end{tabular}

The maximum values of active power $P_{\max } \mathrm{EPS}^{\prime \prime} \mathrm{A}^{\prime \prime}$ and energy demand $E_{\mathrm{EPS}} \mathrm{A}^{\prime \prime}$ of the considered EPS " $\mathrm{A}$ " substation in the island operating condition $\mathbf{F}-\mathbf{2}^{*}$ are presented in Table 6.

\section{Analysis of the Operational Reliability Improvement of the Considered Network by Integrating the BESS}

With reference to the data presented in Table 2 concerning the number of considered network failure events that occurred in 2018, the integration of substation EPS " $\mathrm{A}$ " with BESS will reduce the frequency of power outages. This will also be translated into reducing the frequency of shortages of energy supplies to consumers.

Table 16 compares the number of network failures and power outages before and after the implementation of BESS in the EPS " $\mathrm{A}$ " substation. The number of events before BESS implementation is represented by the one-year (2018) data obtained from the local DSO (see Table 2), while the number of events after the BESS implementation is the approximate and simulated data for the following years in relation to 2018 .

Table 16. Comparison of the number of power outages in the considered network before and after the BESS implementation.

\begin{tabular}{ccccc}
\hline Duration of Failure & $\begin{array}{c}\text { Number of Events } \\
\text { before the BESS } \\
\text { Implementation }\end{array}$ & $\begin{array}{c}\text { Number of Events after the BESS } \\
\text { Implementation }\end{array}$ & $\begin{array}{c}\text { Number of Customers Affected by } \\
\text { the Failure (Customers in Relation } \\
\text { to SAIFI) }\end{array}$ \\
\hline from 3 min to $1.5 \mathrm{~h}$ & 74 & $\mathbf{1 4}$ & $\downarrow$ & up to 3224 \\
\hline from $1.5 \mathrm{~h}$ to $24 \mathrm{~h}$ & 45 & $\mathbf{3 1}$ & $\downarrow$ & up to 3224 \\
\hline longer than $24 \mathrm{~h}$ & 7 & 7 & - & up to 1876 \\
\hline
\end{tabular}

BESS implementation impact on the number of events: $(\downarrow)$-reduction; (-)—no effect.

The implementation of BESS in EPS "A" will contribute to the total reduction in previously occurring power outages in the time interval from $3 \mathrm{~min}$ to $1.5 \mathrm{~h}$ (reduction of 74 events) and partial limitation of the occurrence of power outages in the time interval exceeding $1.5 \mathrm{~h}$ (reduction by 14 events). Some of the previous outages with a duration of more than $1.5 \mathrm{~h}$ will now be less than $1.5 \mathrm{~h}$, and will be moved to the range of $3 \mathrm{~min}$ to $1.5 \mathrm{~h}$.

\section{Cost Comparison of Expanding the HV Line with the Implementation of the BESS}

The implementation of an additional HV supply line for the EPS " $\mathrm{A}$ " substation as a double-side power supply or replacement of the overhead line with a cable would be one of the solutions enabling the continuity of the power supply. The distance to the nearest connection point from the additional $110 \mathrm{kV}$ line is about $40 \mathrm{~km}$, while the approximate length of the current overhead $110 \mathrm{kV}$ line is $30 \mathrm{~km}$. Approximate costs are shown in Table 17. 
Table 17. Approximate cost of implementing or replacing the $110 \mathrm{kV}$ line.

\begin{tabular}{lccc}
\hline \multicolumn{1}{c}{ Technology } & $\begin{array}{c}\text { Length } \\
{[\mathbf{k m}]}\end{array}$ & $\begin{array}{c}\text { Approximate Cost } \\
\text { (Million EUR) }\end{array}$ & Conclusion \\
\hline $\begin{array}{l}\text { Overhead line on traditional } \\
\text { transmission tower }\end{array}$ & $\sim 40$ & $\sim 4.27$ & New additional line \\
\hline $\begin{array}{l}\text { Overhead line on forestry } \\
\text { tubular transmission tower }\end{array}$ & $\sim 40$ & $\sim 5.45$ & New additional line \\
\hline Underground cable & $\sim 30$ & $\sim 20.72$ & $\begin{array}{c}\text { Replacement of the } \\
\text { overhead line }\end{array}$ \\
\hline
\end{tabular}

* Approximate implement cost in Poland in 2019.

These investments are relatively expensive and economically unprofitable. A cost comparison of additional line implementation or $110 \mathrm{kV}$ line replacement with the proposed extension of the EPS "A" substation with BESS is shown in Table 18.

Table 18. Comparison cost of implementation or replacement of a $110 \mathrm{kV}$ line with implemented BESS.

\begin{tabular}{lc}
\hline \multicolumn{1}{c}{ Technological Solution } & Approximate Cost (Million EUR) \\
\hline New additional line & $\sim 5.45$ \\
\hline Replacement from overhead line to cable line & $\sim 20.72$ \\
\hline Implementation of BESS energy (Li-ion technology) & $\sim(0.875-1.080)$ \\
\hline
\end{tabular}

\section{Conclusions}

The aim of this paper was to present the method of improving the power continuity supply in the area of the power network with the possibility of island operation by imple-

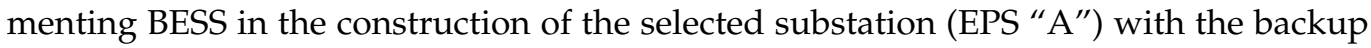
power function, and to present the authorial method of optimal BESS dimensioning and selecting of ES technology.

The use of an optimally sized BESS with the backup power function will allow the power to be supplied to a separated area of the power network during island operation in the proposed time, for example $1.5 \mathrm{~h}$, at the maximum load of the substation (EPS " $\mathrm{A}$ ") in which the BESS would be implemented. This would significantly improve the continuity of the power supply by reducing the occurrence of power interruptions, as shown in Table 16. The BESS implementation may contribute to a reduction in occurrences of power interruptions from 74 to 14 in the time interval from $3 \mathrm{~min}$ to $1.5 \mathrm{~h}$, and from 45 to 31 in the time range from $1.5 \mathrm{~h}$ to $24 \mathrm{~h}$.

For optimal BESS dimensioning ( $P_{\mathrm{ES}}$ and $\left.E_{\mathrm{ES}}\right)$, the method used was the authors' averaging method, whereby the $1 \mathrm{~s}$ real power measurement data $P_{\text {avg (1-s) }}$ were overlaid by a $15 \mathrm{~min}$ moving average window. This method is presented in Section 3.1. This method can also be used for the dimensioning of the ES, whose functions have different purposes, for example: peak shaving, load following, energy arbitrage.

Additionally, we analysed the possibility of implementing an additional $\mathrm{HV}$ line as a double-side supply of the considered substation or replacement of the existing HV overhead line with a cable line, which would also translate into network reliability improvement. Costs were compared with the more profitable BESS implementation and are presented in Table 18. The cost of building an additional power line would exceed EUR 5 million, and the BESS (to ensure continuity of the power supply, for example, $1.5 \mathrm{~h}$ ) implementation into the construction of substations supplying network areas that are exposed to frequent power failures of main HV lines would cost slightly over EUR 1 million, which indicates a better solution. 


\section{Future Work}

The ES oversizing due to the choice of Li-ion technology and the ES authorial dimensioning method used would allow the prolongation of the service life of the storage and, at the same time, using an appropriate control algorithm would perhaps allow the assumed benefit (emergency power supply-for an exemplary time interval) to be maintained in the emergency of one PCS module or one ES cell chain, but these will be the topic of the next paper.

Author Contributions: M.S. was the principle author tasked with coordinating and writing the article; S.W. performed the simulation on real measurement data; M.J. and J.K. performed measurement of power flow and analysed the object; G.B. responsible for the development of the concepts for connecting the energy storage to the power system. The authors equally contributed to the creation of the proposed system. All authors have read and agreed to the published version of the manuscript.

Funding: This research received no external funding.

Institutional Review Board Statement: Not applicable.

Informed Consent Statement: Not applicable.

Data Availability Statement: Not applicable.

Acknowledgments: The research was conducted in cooperation with the PGE Dystrybucja S.A.

Conflicts of Interest: The authors declare no conflict of interest.

\section{References}

1. EN 50160:2010. Voltage Characteristics of Electricity Supplied by Public Electricity Networks; iTeh, Inc: Newark, DE, USA, 2010.

2. Tesarova, M.; Nohec, K. Voltage and frequency stability analysis of an island-mode LV distribution network. In Proceedings of the 15th International Scientific Conference on Electric Power Engineering (EPE), Brno, Czech Republic, 19 June 2014.

3. Batkiewicz-Pantuła, M. The problem of determining the coefficient of flicker in accordance to normative regulation. In Przeglad Elektrotechniczny; Wydawnictwo SIGMA-NOT: Warszawa, Poland, 2020; ISSN 0033-2097.

4. Waldemariam, L.; Cuk, V.; Cobben, S.; van Waes, J. Regulation and classification of voltage dips. In Proceedings of the 24th International Conference \& Exhibition on Electricity Distribution (CIRED), Geneva, Switzerland, 12-15 June 2017.

5. Liu, Z.; Milanović, J.V. Probabilistic Estimation of Voltage Unbalance in MV Distribution Network With Unbalanced Load. IEEE Trans. Power Deliv. 2014, 30, 693-703. [CrossRef]

6. Latka, M.; Hadaj, P. Technical and statistical analysis of the failure of overhead lines and its Impact on evaluating the quality of the power supply. In Proceedings of the Progress in Applied Electrical Engineering (PAEE), Koscielisko-Zakopane, Poland, 26 June-1 July 2016.

7. Kornatka, M. Analysis of the variability of indicators SAIDI, SAIFI and MAIFI values in the context of quality regulation. In Przeglą Elektrotechniczny; Wydawnictwo SIGMA-NOT: Warszawa, Poland, 2020; ISSN 0033-2097.

8. $\quad$ Ridzuan, M.O.M.; Djokic, S.Z. Energy Regulator Supply Restoration Time. Energies 2019, 12, 1051.

9. Janiszewski, P.; Sawicki, J.; Kurpas, J.; Mróz, M. Practical ways to Improve SAIDI and SAIFI Power Supply Indicators in an MV Grid. Acta Energetica 2018, 34, 45-50. [CrossRef]

10. Honzález, A.; Riba, J.; Rius, A. Optimal sizing of a Hybrid Grid-Connected Photovoltaic-Wind-Biomass Power System. Sustainability 2015, 7, 12787-12806. [CrossRef]

11. Singh, S.; Singh, M.; Kaushik, S.C. Feasibility study of an island microgrid in rural area consisting of PV, wind, biomass and battery energy storage system. Sci. Direct Energy Convers. Manag. 2016, 128, 178-190. [CrossRef]

12. Mohamad, F.; Teh, J.; Lai, C.-M.; Chen, L.-R. Development of Energy Storage System for Power Network Reliability: A Review. Energies 2018, 11, 2278. [CrossRef]

13. Mitani, T.; Aziz, M.; Oda, T.; Uetsuji, A.; Watanabe, Y.; Kashiwagi, T. Annual Assessment of Large-Scale Introduction of Renewable Energy: Modeling of Unit Commitment Schedule for Thermal Power Generators and Pumped Storages. Energies 2017, 10, 738.

14. Ganesan, S.; Padmanaban, S.; Varadarajan, R.; Subramaniam, U.; Mihet-Popa, L. Study and Analysis of an Intelligent Microgrid Energy Management Solution with Distributed Energy Sources. Energies 2017, 10, 1419. [CrossRef]

15. Suresh, V.; Kaczorowska, D.; Janik, P.; Rezmer, J. Load Flow Analysis in local microgrid with storage. Przeglad Elektrotechniczny 2019, 1, 100-104. [CrossRef]

16. Li, X.; Chalvatzis, K.J.; Stephanides, P. Innovative Energy Islands: Life-Cycle Cost-Benefit Analysis for Battery Energy Storage. Sustainability 2018, 10, 3371. [CrossRef]

17. Koohi-Kamali, S.; Rahim, N.A. Coordinated control of smart microgrid during and after islanding operation to prevent under frequency load shedding using energy storage system. Energy Convers. Manag. 2016, 127, 623-646. [CrossRef] 
18. Nick, M.; Cherkaoui, R.; Paolone, M. Opimal Allocation of Dispersed Energy Storage System in Active Distribution Networks for Energy Balance and Grid Support. Trans. Power Syst. 2014, 29, 2300-2310. [CrossRef]

19. Hesse, H.C.; Schimpe, M.; Kucevic, D.; Jossen, A. Lithium-Ion Battery Storage for the Grid-A Review of Stationary Battery Storage System Design Tailored for Applications in Modern Power Grid. Energies 2017, 10, 2107. [CrossRef]

20. Mazza, A.; Mirtaheri, H.; Chicco, G.; Russo, A.; Fantino, M. Location and Sizing of Battery Energy Storage Units in Low Voltage Distribution Network. Energies 2019, 13, 52. [CrossRef]

21. Koller, M.; Borsche, T.; Ulbig, A.; Andersson, G. Review of grid applications with the Zurrich 1 MW battery energy storage system. Electr. Power Syst. Res. 2015, 120, 128-135. [CrossRef]

22. Worku, M.Y.; Hassan, M.A.; Abido, M.A. Real Time Energy Management and Control of Renewable Energy based Microgrid in Grid Connected and Island Modes. Energies 2019, 12, 276. [CrossRef]

23. Li, J.; Niu, D.; Wu, M.; Wang, Y.; Li, F.; Dong, H. Research on Battery Energy Storage as Backup Power in the Operation Optimization of a Regional Integrated Energy System. Energies 2018, 11, 2990. [CrossRef]

24. Abbas, F.; Habib, S.; Feng, D.; Yan, Z. Optimizing Generation Capacities Incorporating Renewable Energy with Storage Systems Using Genetic Algorithms. Electronics 2018, 7, 100. [CrossRef]

25. Konstantelos, I.; Strbac, G. Capacity value of energy storage in distribution networks. J. Energy Storage 2018, $18,389-401$. [CrossRef]

26. Bahmani-Firouzi, B.; Azizipanah-Abarghooee, R. Optimal sizing of battery energy storage for micro-grid operation management using a new improved bat algorithm. Electr. Power Energy Syst. 2014, 56, 42-54. [CrossRef]

27. Chen, S.X.; Gooi, H.B.; Wang, M.Q. Sizing of Energy Storage for Microgrids. Trans. Smart Grid 2012, 3, 142-151. [CrossRef]

28. Xiao, H.; Pei, W.; Yang, Y.; Kong, L. Sizing of Battery Energy Storage for Micro-grid Considering Optimal Operation Management. In Proceedings of the International Conference on Power System Technology, Chengdu, China, 20-22 October 2014.

29. Liu, P.; Cai, Z.; Xie, P.; Li, H.; Zhang, Y. A Computationally Efficient Optimization Method for Battery Storage in Grid-connected Microgrids Based on a Power Exchanging process. Energies 2019, 12, 1512. [CrossRef]

30. EN 50470-3: 2009. Electricity Metering Equipment (a.c.) Part 3: Particular Requirements—Static Meters for Active Energy (Class Index A, $B$ and C); ISS: Beograd, Serbia, 2009.

31. EN 62055-31. Electricity Metering_Payment Systems_Part 31: Particular Requirements—Static Payment Meters for Active Energy (Classes 1 and 2); IEC: Geneva, Switzerland, 2005. 